\title{
Awareness and current knowledge of breast cancer
}

\author{
Muhammad Akram ${ }^{1 *}$, Mehwish lqbal ${ }^{2}$, Muhammad Daniyal ${ }^{2}$ and Asmat Ullah Khan ${ }^{3,4}$
}

\begin{abstract}
Breast cancer remains a worldwide public health dilemma and is currently the most common tumour in the globe. Awareness of breast cancer, public attentiveness, and advancement in breast imaging has made a positive impact on recognition and screening of breast cancer. Breast cancer is life-threatening disease in females and the leading cause of mortality among women population. For the previous two decades, studies related to the breast cancer has guided to astonishing advancement in our understanding of the breast cancer, resulting in further proficient treatments. Amongst all the malignant diseases, breast cancer is considered as one of the leading cause of death in post menopausal women accounting for $23 \%$ of all cancer deaths. It is a global issue now, but still it is diagnosed in their advanced stages due to the negligence of women regarding the self inspection and clinical examination of the breast. This review addresses anatomy of the breast, risk factors, epidemiology of breast cancer, pathogenesis of breast cancer, stages of breast cancer, diagnostic investigations and treatment including chemotherapy, surgery, targeted therapies, hormone replacement therapy, radiation therapy, complementary therapies, gene therapy and stem-cell therapy etc for breast cancer.
\end{abstract}

Keywords: Breast cancer, Chemotherapy, Gene therapy, Stem cell therapy

\section{Background}

Breast cancer is the most common cancer and also the primary cause of mortality due to cancer in female around the World. About 1.38 million new breast cancer cases were diagnosed in 2008 with almost $50 \%$ of all breast cancer patients and approximately $60 \%$ of deaths occurring in developing countries. There is a huge difference in breast cancer survival rates worldwide, with an estimated 5-year survival of $80 \%$ in developed countries to below $40 \%$ for developing countries [1]. Developing countries face resource and infrastructure constraints that challenge the objective of improving breast cancer outcomes by timely recognition, diagnosis and management [2]. In developed countries like the United States, about 232,340 female will be diagnosed and death of 39,620 female will occur due to breast cancer in 2013 [3]. The lifetime risk of developing breast cancer in an

\footnotetext{
${ }^{*}$ Correspondence: upr2014@yahoo.com

${ }^{1}$ Department of Eastern Medicine and Surgery, Directorate of Medical

Sciences, GC University Faisalabad, Old Campus, Allam lqbal Road,

Faisalabad 38000, Pakistan

Full list of author information is available at the end of the article
}

American female is $12.38 \%$ [3]. The significant decline in morality due to breast cancer in the United States from 1975 to 2000 is attributed to constant enhancement in both screening mammography and management [4]. According to the World Health Organization (WHO), enhancing breast cancer outcome and survival by early detection remains the foundation of breast cancer regulations. Different modern medicines are prescribed to treat breast cancer. Medical therapy of breast cancer with antiestrogens such as raloxifene or tamoxifen might avoid breast cancer in individuals who are at increased possibility of developing it [5]. Surgery of both breasts is an added preventative measure in some increased probability of developing cancer in female. In patients who have been identified with breast tumor, different strategies of management are used such as targeted therapy, hormonal therapy, radiation therapy, surgery and chemotherapy. In individuals with distant metastasis, managements are typically aimed at enhancing life quality and survival rate [6]. The unpleasant side effects of breast cancer treatment are one of the most motivating factors to find some alternative methods. The use of herbs for treating the patients 
having breast cancer is considered a natural alternative, because some plants may contain properties that naturally have the ability to treat breast cancer [7-11].

\section{Epidemiology}

Currently, one in twelve females in Britain between age of 1 and 85 years gets breast cancer. With one million new cases of cancers reported in the World, breast cancer is common in females and comprises $18 \%$ of all women cancer. Incidence of breast cancer is predicted to increase to 85 per 100,000 women by 2021 [12]. In 2012, 1.67 million new cases of breast cancer were diagnosed that is $25 \%$ of all cancers among women. Ferlay et al. [13] stated that 883,000 cases are in less developed countries and 794,000 in most developed countries. According to the data, 145.2 women in Belgium and 66.3 in Poland between 100,000 suffer from breast cancer [14]. Incidence of breast cancer in the United States is one out of eight women and In Asia one woman suffers from breast cancer out of 35 . In Iran, there are 10 cases in 100,000 populations and 7000 new cases have been reported annually [15]. Prevalence of breast cancer is increasing in Pakistan [16-18]. Breast cancer is found mostly in highly populated areas of South Asian developing counties [19, 20]. Breast cancers in males have been detected in Northern areas of Pakistan [21]. Yang et al. [22] stated that new cases of breast cancer in China were 168,013 in 2005 and 121,269 in 2000.

\section{Anatomy of breast}

Both males and females have breasts [23]. The breast is made up of fatty tissue called adipose tissue [24]. The female's breasts usually contain more glandular tissue than that of the males [25]. Female breasts contain 12-20 lobes which are further divided into smaller lobules [26]. These lobes and lobules are connected via milk ducts. The adipose tissue of the breast is supplied by a network of nerves, blood vessels, lymph vessels, lymph nodes, and is also composed of fibrous connective tissue and ligaments [27]. The female breast is designed to provide optimal nourishment for babies and to provide sexual pleasure for the female herself. The breasts are glandular organs that are very sensitive to hormonal changes in the body [28]. They adopt cyclic changes in synchrony with the menstrual cycle. They are closely associated with the genital system of females. Nipple stimulation enhances secretion of prolactin from the pituitary gland. This hormone also affects the uterus and can cause contractions. Lymph node draining the breast tissues is also found in the armpits. After a female has had a baby and her milk comes in, mother may develop striking swelling under arms from engorgement of the breast tissue in that region. Breasts come in all sizes and shapes, as do nipples. Most female possess one breast that slightly smaller than the other [29]. The epidermis of the areola and nipple is very much pigmented and to some extent wrinkled, and the nipple skin contains several apocrine and sebaceous sweat glands and somewhat small hair. The 15-25 milk ducts go into the base of the nipple, wherever they expand to synthesize the milk sinuses. These milk ducts functions as the carriers of milk towards the nipples [30]. Slightly under the surface of nipple, these sinuses end in coneshaped ampullae. The spherical areola is present around the nipple and is between 15 and $60 \mathrm{~mm}$ in diameter. Sebaceous glands, sweat glands and lanugo hairs are present on its skin, Montgomery's glands, are big, modified sebaceous glands with tiny milk ducts that open into Morgagni's tubercles in the areola epidermis. Deep in the nipple and areola, several smooth muscle fibers are set circularly and radially in the dense connective tissue and longitudinally alongside the lactiferous ducts that lengthen up into the nipple. These muscle fibers are cause emptying of milk sinuses, nipple erection and contraction of areola. The greater part of the breast parenchyma expand inferiorly from the point of the 2nd or 3rd rib to the inframammary fold, which is at about the point of the 6th or 7th rib, and crossways from the border of the sternum to the anterior axillary line. The mammary tissue also expands erratically into the axilla as the glandular tail of spence. The posterior surface of the breast rests on segment of the fasciae of the pectoralis major, rectus abdominis muscles, external abdominal oblique and serratus anterior.

\section{A global prospective}

Globalization, which thus greatly characterizes our period, was primarily linked with commercial-related actions, consequently with ecological concerns, and especially in recent times with the dark truth of terrorism. Up till now the "globalization" of numerous human being actions, together with health care, has been departing on for several decades, enhancing in step with improvement in information machinery. Correctly or incorrectly, and whether planned or not, numerous clinicians in developing countries keep an eye on what Americans are achieving, or are alleged to be achieving, as "state of the art" and recent most excellent performance that ought to be copied. The actions reviewed and our current narration with transplantation of bone marrow recommends that present "standard of care" United States described interventions are inappropriate to global utilization. Unluckily, extensive deficiency of community wellbeing strategies to breast cancer has made understanding of such rights for females not viable. Impractical, deadly, and extremely expensive treatments for breast cancer cannot assist the 
huge number of females in the earth at danger for or who develop breast cancer [31].

\section{Types of breast cancer}

According to site, it is divided into invasive and noninvasive breast cancers

\section{Non-invasive breast cancer}

It is a cancer that has not extended away from the lobule or ducts where it situated [32]. An example of a kind of non-invasive breast cancer is ductal carcinoma in situ. Ductal carcinoma in situ appears when atypical cells develop within the milk ducts, however have not extended to close proximity of tissue or outside. The word "in situ" describes "in place." Even though the atypical cells have not extended to tissues outer the lobules or ducts, they can progress and grow into invasive breast cancer. The normal background of every scientific unit is demonstrated and a biological understanding of the accessible information is presented. Lobular carcinoma in-situ is understood merely a risky sign moderately than a predecessor for the successive growth of invasive cancer, so that one time the judgment is made, additional operative involvement is avoidable and sequential follow-up only is suggested. The management of ductal carcinoma in-situ should be kept in mind that breastpreserving treatment is at the present considered best therapy of breast cancer, the illness we are attempting to stop [33]. The pitfalls of suggested management based on retrospective statistics are have been taken into account and the requirement to conduct clinical studies intended to establish the best possible beneficial treatment of noninvasive breast cancer is affirmed [34].

\section{Lobular carcinoma in situ (LCIS)}

This type of breast cancer develops into breast lobules [35]. The breast cancer has not extended exterior to the lobules into the breast tissue [36]. Lobular carcinoma in situ is usually identified as non-invasive breast cancer [37].

\section{Ductal carcinoma in situ}

It is the most general kind of non-invasive breast cancer, is limited to the breast duct. Example of ductal carcinoma in situ is ductal comedocarcinoma [38].

\section{Invasive breast cancer}

It exists when abnormal cells from within the lobules or milk ducts split out into close proximity of breast tissue [39]. Cancer cells can pass through the breast to different parts of the body through immune system or the systemic circulation [40]. They may move early in the development when the tumor is a minute or afterward when the tumor is huge Invasive breast cancer is most occurring general carcinoma in females. The regions of elevated threat are the prosperous populations of Australia and Europe wherever $6 \%$ of females suffer from invasive breast cancer prior to 75 years of age. The prevalence of breast cancer enhances quickly with increasing age [41]. Invasive breast cancer that extends to different organs of the body is also recognized as metastatic breast cancer [42]. Most common organ to which these cells spread are brain, bones, lungs and liver. These cells once more segregate and expand irregularly and produce new cancers. The new forming cells are developing in different part of the body, it is still breast cancer [43].

\section{Infiltrating lobular carcinoma (ILC)}

Infiltrating lobular carcinoma is also recognized as invasive lobular carcinoma. ILC originates in the milk glands (lobules) of the breast, but frequently extends to other areas of the body [44].

\section{Infiltrating ductal carcinoma}

Infiltrating ductal carcinoma is also recognized as invasive ductal carcinoma. IDC originates in the milk ducts of the breast and extends to the duct wall, invading the breast fatty tissues and probably other parts of the body [45].

\section{Medullary carcinoma}

Medullary carcinoma is an invasive breast cancer that designs a discrete margin normal tissue and medullary tissue [46].

\section{Mucinous carcinoma}

It is recognized as colloid carcinoma, mutinous carcinoma is a uncommon breast cancer created by the mucus-forming cancer cells. Females with mutinous carcinoma usually have an improved prediction than females with additional general kinds of invasive carcinoma [47].

\section{Tubular carcinoma}

Tubular carcinomas are a particular kind of invasive breast carcinoma. Females with tubular carcinoma usually have an improved prospects than women with additional general kinds of invasive carcinoma [48].

\section{Inflammatory breast cancer}

Inflammatory breast cancer is the form of swollen breasts (red and warm) with dimples and/or broad ridges due to cancer cells blocking lymph vessels or channels in the skin over the breast. Though inflammatory breast cancer is uncommon and is tremendously fast-growing [49]. Treatment involves vigilant synchronization of all multidisciplinary strategies, including radiation therapy, surgery, 
chemotherapy and imaging. The administration of neoadjuvant chemotherapy has accorded considerably to enhancement in general survival from the time when the earliest report of this matter and has performed the function of locoregional treatment such as radiation and surgery significant to sustained improvements in this ailment [50].

\section{Paget's disease of the breast}

It is the uncommon type of breast cancer that usually shows visible changes to the nipple of the breast [51]. Its symptoms include red itchy rashes involving the nipple and then it can sometime spread to the normal skin as well. However it resembles with the other skin conditions such as eczema and psoriasis but it can be differentiated as the other skin conditions usually affects both the breasts and can start from the areola rather than the nipple of the breast however Paget's disease of the breast most often affects only one breast and starts with the nipple of the breast instead of areola (breastcancercare.org.uk) Nearly 1-3\% of all the breast cancers are Paget's disease and can affect both men as well as women. The actual theory behind the pathogenesis or development of Paget's disease of the breast isn't clear yet however there are few theories supporting it's pathogenesis. Their warning signs include bleeding and oozing of discharge from the nipple, flattening or inversion of nipple, lump found in the breast etc. It can be diagnosed by using punch biopsy. It's prognosis is good if it remains within the nipple or in ducts of the breast [52].

\section{Phyllodes tumor}

Phyllodes tumors are can be either benign or malignant [53]. Phyllodes tumors develop in the connective tissues of the breast and may be treated by surgical removal [54]. Phylloides tumors are extremely uncommon; fewer than 10 females die of this kind of breast cancer every year in the United States [55].

\section{Triple-negative breast cancer}

Breast cancer is at the present extensively documented that is a heterogeneous disorder with special sub-forms, distinguished by means of their dissimilar clinico-pathological characteristics, prevision and responses to management. Triple-negative breast cancer is described by the deficiency of progesterone receptor, human epidermal growth factor receptor 2 and estrogen receptor expression [56]. This type is mainly destructive, commonly observed in premenopausal females, and is responsible for $10-15 \%$ of cases in white females, with a elevated occurrence [57].

\section{Pathogenesis of breast cancer}

The breast is a complex tubulo-alveolar organ fixed within an asymmetrical connective tissue [58], that go through a chain of alteration from child bearing age to senility. The changes seen with every menstrual cycle and pregnancy guided us to assume the occurrence of precursor cells in the mature tissue that is able of synthesizing novel duct-lobular units [59]. The typical breast architecture contains a stratified epithelium bordered by a basement membrane and fixed in a template of blood vessels, lymphatic and stromal cells [60]. In the usual breast, the stratified epithelium comprised of two dissimilar cell populations, myoepithelial and epithelial, which can be distinguished by way of immunohistochemical staining with antibodies against myosin and CK, correspondingly. It has been postulated that the creation of cellular heterogeneity in breast disorders depends on the primary developmental series of the usual breast. This heterogenicity of the breast carcinoma might happen from the neoplastic change of either myoepithelial or epithelial cell, or yet from a stem cell that has the ability to develop into myoepithelial or epithelial cells [61]. According to the oncology of breast cancer, neoplastic cells differ from the normal body cells. Normal tissues of the body have limited growth promotion and regulation which helps to keep the structure and functions of tissues usual. However, cancerous cells have prolonged and chronic proliferation without any external stimuli [62]. Cancer cells overcome the growth suppressor genes [63]. Breast cancer is a malignant disease that initiates in the breast cells. Like other malignant tumors, there are numerous causes that can increase the possibility of developing breast cancer. Injure to the deoxyribonucleic acid (DNA) and hereditary alteration can guide to breast cancer have been associated with the exposure of estrogen. Some patients inherit fault in the deoxyribonucleic acid (DNA) and genes like the P53, BRCA1 and BRCA2 among others. The patients with a family history of breast or ovarian cancer have possibility of developing breast cancer [64]. Neoplastic cells require considerable potential to multiply and convert into a massive tumor [65]. The immune system usually tries to find out cancer cells and cells with injured deoxyribonucleic acid (DNA) and demolish them. Breast cancer might be outcome of malfunction of such an useful immune defence and surveillance. Breast cancer commonly occurs due to an association between genetic and environmental factors. RAS/MEK/ERK pathway and PI3K/AKT pathway defend normal cells from cell suicide. When mutation occurs in genes that are involved in encoding of these protective pathways, the cells become unable of committing suicide when they are no longer required which then leads to development of cancer. These mutations were confirmed to be experimentally associated with estrogen exposure [66]. It was recommended that deformity in the growth factors signaling can assist growth of malignant 
cells. Over expression of leptinin breast adipose tissue enhances proliferation of cell and cancer [67]. These are numerous growth factors signaling and other factors that interrelate between epithelial cells and stromal cells. Interruption in these might result in development of breast cancer. In cancer cells, enzyme telomerase turns away the chromosomal shortening and allows the extensive replication of cells [68]. Tumor cells get their nutrients and oxygen supply by angiogenesis [69]. Cancer cells break their boundaries and can enter into the blood, lymphatic tissues and other tissues of the body to produce a secondary tumor [70].

\section{Causative factors and associated risks of breast carcinoma}

Breast cancer is the leading cause of death among British females who are 40-55 years of age. Breast cancer is more common in single women than in married women $[71,72]$. The breast is an estrogen sensitive organ. Many females who have been on birth control pills or estrogen replacement have found that the medications result in enlarged and often tender breasts. The activity of this medication, combined with the standard western high fat, low fiber diet, which over-stimulates breast tissue, could be a trigger for breast cancer. Incidence of breast cancer is higher in women above 50 years of age and 2 cases per 1000 are reported in this age group. Epidemiological investigations have also suggested that those women who have many children possess lower risk of breast cancer than those women who have fewer children. Incidence of breast cancer is $10.04 \%$ among all cancers and, most commonly occurs in 40-50 aged women. Mean age of breast cancer in Iranian women is 48 years [73]. An association of clinic pathological characteristic and breast cancer subtypes has been determined in Iranian women [74]. Breast cancer mostly occurs in obese women [75]. Depression is most commonly found in women with breast cancer [76]. Andsoy et al. [77] conducted a study to investigate knowledge of colorectal, cervical and breast cancer. For this study 226 working nurses were screened. It is very interesting that certain epidemiological studies have claimed that women who give birth to their child before they attain the age of 20 years are known to have decreased risk of breast cancer than those women who have not given birth to any child or who have given birth to their first child after the age of 30 years. The risk increases with age rapidly during premenopausal and slowly during post-menopausal life. Breast feeding decreases the risk of breast cancer [78]. Menopause resulting from surgical removal of ovaries (oophorectomy) decreases the risk [79]. Presence of certain kinds of benign tumours in breast increases the risk of malignancy [80]. The ovaries stop producing the female hormones once the menopause sets in, but in obese women the fatty tissue can provide the estrogen as it is capable of producing it. This increase in hormone production seems to increase the risk of breast cancer in obese post menopausal women. Deficiency of vitamin $\mathrm{D}$ and lack of sun exposure is considered to be the important cause of breast cancer [81]. It is found to be more in women than men [82]. The risk of breast cancer increases with age however rarely found before the age of 20 years [83]. Carcinoma in one breast can increase the risk by four times in another breast. While the patients that have the history of ovarian, endometrial or colon cancer have 1-2 times increased risk to develop breast carcinoma [84]. A female who has had breast cancer has an enhanced danger of occurring breast cancer in the other breast [85]. The minimal role of the gene has been established in the development of breast cancer. BRCA-1 (breast cancer susceptibility gene) is considered to be the cause of $5-10 \%$ of breast cancer that is transferred from either father or mother to the next generation. The study indicates that right environmental conditions are required for cancer promoting gene for expression. Certain families have been recognized with a genetically higher incidence of early onset breast cancer. If some individuals of the female's family have had a specific kind of cancer, female may have an enhanced danger risk of breast cancer [86]. The danger is maximum if the affected family member had breast cancer at a juvenile period, had cancer in both breasts, or if female is a close family member. First-degree family members such as daughter, sister and mother are mainly significant in estimating threat. Numerous second-degree relatives such as an aunt and grandmother with breast cancer might also enhance threat. Breast cancer in a male enhances the danger for the entire close female relatives. Women who have a positive family history of breast carcinoma are 2-4 times more likely to develop the cancer, especially the females who are the carriers of BRCA1 or BRCA2 genes have the significant chance to develop carcinoma of breast [87]. Breast cancer affects both male and females; though, the prevalence is more in female as compared to male. Generally, females are at 100-fold increased danger of breast cancer than male [88]. Early menarche, nulli parity, pregnancy after the age of 30 , oral contraceptives or hormone replacement therapy all these factors can increase the risk of breast cancer [83]. Steroid hormones include androgens, progesterone and estrogen, which belong to a cluster of structurally connected hormones known as sex hormones that are released into the blood by the gonads and adrenal glands. They are synthesized from single general precursor, cholesterol through a reaction catalyzed by numerous enzymes to make a large diversity of hormones for diverse target organs and tissues [89]. This procedure is well regulated and the discharge of these 
hormones into the systemic circulation. These hormones cross the plasma membrane to reach the target cells and bind to specific receptors called steroid hormone receptors to exert their activity [90]. Oestrogens have important activities on differentiation, growth and performance of several tissues, including urogenital system of man and women, cardiovascular system, brain, uterus and breast [89]. In accordance with this, Kato et al. [91], reported that the progression of reproductive organ cancer like prostate and breast cancer frequently occurs because of the androgens, progesterone and estrogen, which exert numerous biological activities in normal as well as abnormal cells. The study indicates that the development of normal and abnormal epithelial cells of the breast can be modulated by stromal cells of the breast and can release growth factors after stimulation by the endogenous hormones. An aromatase enzyme is found in adipose tissues, which makes estradiol from the precursor molecule, cholesterol. Fat cells are found in excess amount in breast of aged females; therefore, the quantity of estradiol is higher in breast tissues of post menopausal female than their plasma level [92]. This most likely is responsible for the increasing occurrence of breast cancer in aged female and assists the action of steroid hormones in breast cancer pathogenesis. Benign tumors and proliferative lesions without or with atypia can increase the risk of breast cancer [85]. Breast cancer has been linked with high level of dietary fats and low level of certain nutrients for various years [93]. Animal fat stimulates colonal bacterial to form estrogen from cholesterol found in the diet, thus increasing level of estrogen in the body. The body fat is also involved in synthesis of oestrone, a type of estrogen. Obesity, increased fat consumption, radiation therapy [94]. Evidence is accumulating that certain environmental pollutants contribute to estrogenic activity and may contribute to the prevalence of breast problems in the industrialized world. Alcohol consumption is linked with breast cancer risk. This association was felt to be secondary to the fact that consumption of alcohol enhances level of hormones in the blood [95].

\section{BRCA1 and BRCA2}

These are two genes that have been recognized as possessing the firm relationship with breast cancer. Both emerge to contain comparable biological activities such as DNA damage repair and, in their variant kind, they enhance the danger of breast cancer and other ovarian cancers. The preeminent knowledge accessible to date is based on a joint investigation of 22 researches, 11 which established that the prevalence of breast cancer is $65 \%$ at 70 years of age in women who acquired a BRCA1 gene and $45 \%$ in those women who are carriers of BRCA2 genes. The prevalence of breast cancer in carrier of these genes is 10-30 times more than those females that have no inherited gene variants. In spite of the big boost in breast cancer danger linked with BRCA1 and BRCA2 genes, they are responsible approximately $5 \%$ of all breast cancers, as merely 1 in 1000 females have acquired one of them. There are several tribal Subgroups in which BRCA1 and BRCA2 genes are more possible to be innate (e.g. approximately $1 \%$ of females of Ashkenazi Jewish descent have acquired increased risk BRCA1 or BRCA2 genes; analogous variants are moreover familiar in women belong to Iceland and different Scandinavian countries). Individual risk indicator as an outcome of hereditary testing for BRCA1 and BRCA2 remains a demanding experience. Almost 2000 variants have been found in the two genes (BRCA1 and BRCA2) and, for numerous; it is yet not recognized whether or not they enhance prevalence of breast cancer. One possible sign is the site of the variant in the gene; it indicates that variants in few parts of the genes might cause bigger threat of breast cancer than others $[96,97]$. Even though all females who acquire a BRCA1 or BRCA2 variant do not essentially cause breast cancer, it is uncertain what other determinants such as genetic or environmental persuade the risk of breast. There is also promising data that determinants for breast cancer might perform in a different way for carriers of BRCA1 or BRCA2 variants than for females lacking hereditary vulnerability because of these genes [98]. Literature review also recommends that high-risk genes other than BRCA1 and BRCA2 possibly enhance the risk of developing breast cancer, mainly for younger females.

\section{Mortality}

Fifth most common cause of cancer death is breast cancer. The mortality and age standardized prevalence of breast cancer is higher in the United States compared to world. In Poland, seventeen percent of disease cases occur due to cancer and 14\% deaths occur due to cancerous changes. Worldwide death due to breast cancer calculated in 2004 was 519,000 [99]. In the United States alone, approximately $1,208,000$ cancer cases are reported per year and that some 538,000 people die from the previous manifestation of this disease condition, representing about one fifth of the total annual deaths from all causes [74].

\section{Stages of breast cancer}

According to the report of breast cancer.org Stages of the breast cancer depends upon the size and type of tumor and how much the tumor cells have been penetrated in the breast tissues [100]. Whereas stage 0 describes the non invasive and stage 4 describes the invasive kind of tumor. Descriptions of those tumor stages are: 


\section{Stage 0}

This is the non invasive stage of tumour which indicates that both cancerous and non cancerous cells are within the boundaries of that part of the breast in which the tumor begins to grow and no evidence found of their invasion in the surrounding tissues of that part, the example of this tumour stage is ductal cell carcinoma in situ (DCIS) [101].

\section{Stage 1}

This stage describes as the invasive breast carcinoma and microscopic invasion is possible in this stage. It has two categories that are $1 \mathrm{~A}$ and $1 \mathrm{~B}$ stage. The category 1A describes the tumor which measures up to $2 \mathrm{~cm}$ and none of the lymph nodes are involved in it while stage $1 \mathrm{~B}$ describes that small group of cancer cells larger than $0.2 \mathrm{~mm}$ founds in lymph node [102].

\section{Stage 2}

Stage 2 also has two categories $2 \mathrm{~A}$ and 2B. Stage $2 \mathrm{~A}$ describes that the tumour is found in axillary lymph nodes or in sentinel lymph nodes but no tumor found in breast. The tumor can be smaller or larger than $2 \mathrm{~cm}$ but not more than $5 \mathrm{~cm}$. However stage $2 \mathrm{~B}$ describes that the tumor could be larger than $5 \mathrm{~cm}$ but can't reach to the axillary lymph nodes [103].

\section{Stage 3}

It has been divided into three sub categories that are $3 \mathrm{~A}$, $3 \mathrm{~B}$ and $3 \mathrm{C}$. Amongst which stage $3 \mathrm{~A}$ describes that no tumor is found in breast but it can be found in 4-9 axillary lymph nodes or in sentinel lymph nodes while stage $3 \mathrm{~B}$ describes that the tumour can be of any size but have caused swelling or ulcer on the skin of the breast and can have spread up to 9 axillary lymph nodes or to sentinel lymph nodes stage $3 \mathrm{~B}$ can be considered as inflammatory breast cancer which includes red, warm and swollen skin of the breast. However stage $3 \mathrm{C}$ describes the spread of tumor up to 10 or more than 10 axillary lymph nodes and it also have involved the lymph nodes above and below the clavicle [104].

\section{Stage 4}

This is the advanced and metastatic stage of cancer and this stage describes the spread to other organs of the body that is lungs, bones, liver brain etc [105].

\section{Diagnosis}

\section{History and physical examination}

The clinical history of patients with breast cancer is aimed at investigating cancer threat and demonstrating the occurrence or lack of manifestations indicative of breast illness [106]. It must comprise age at menarche, menopausal condition, earlier pregnancies and utilization of hormone replacement therapy after menopause or utilization of oral contraceptives. Personal history as well as family history should be carried out in detail. Personal history includes age at diagnosis of breast cancer, previous breast biopsies and treatment of other cancer with use of radiations. Family history includes history of ovarian cancers and breast cancer in first degree relatives. Patents should be examined for particular manifestations such as breast pain, weight loss, pain in bone, tiredness and nipple discharge [107]. Physical examination includes inspection of breasts, area around neck and collarbone, and armpits (axillae) carried out by clinicians [108]. Breasts are observed for any deformities such as lumps or other manifestations of breast cancer. Lymph nodes are also examined that are usually enlarged in patients with breast cancer.

\section{Self examination}

Usefulness of the breast self-examination is contentious because the advantage in conditions of reduced deaths has not been established [109]. Most physicians educate females to carry out monthly BSE to become recognizable with their usual structure and authorize them with reference to their own healthcare [110]. Women are guided for self examination of the breast cancer. Women can find abnormalities in size and shape of breast on self examination [111-113]. Alipour et al. [114] conducted a study to investigate the the SMS based and paper based paper learner's satisfaction and learning effect. Gynecologists gave printed materials and text messages regarding facts of breast cancer and breast cancer tests. Doctors found higher motivation and better effects in the SMS group than the printed material group. Sreedharan et al. conducted a study in United Arab States hospitals. Self administered structured questionnaire was used to investigate practices of self examination and knowledge. Satisfactory results were found from this study [115]. Ozkan et al. [116] investigated the level of knowledge regarding self examination of the breast cancer among 113 midwifery and nursing students. These researches have shown that continuous education program about breast cancer can raise the awareness among the population. Ceber et al. [117] conducted studies on breast self examination and health beliefs of Turkish women and stated that physical illnesses and early death can be prevented by early diagnosis of breast cancer. He further stated that one out of seven patients with breast cancer is diagnosed in time. Beydag and Karaoglan [118] investigated the awareness about breast self examination in 1st and 4th years students and concluded that 4th years students have more knowledge about breast examination than the 1 st years students. 


\section{Ultrasound breast imaging}

There are numerous researches behind the application of adjunctive screening ultrasound in elevated hazard women with thick breast tissue, which reveals a significant but established figure of false positives [119, 120]. There is no randomized clinical study conducted for investigation of impact of screening ultrasonography on mortality rates of breast cancer. Entire breast ultrasound might permit the Physicians to display for breast tumors not measured by long-established mammography, particularly in thick breasts wherever mammography sensitivity is lesser [121]. Ultrasound breast imaging shows the size and position of tumour whether it is filled with fluid or is solid and needs to be biopsied to rule out cancer. This examination is quickly becoming a routine procedure for diagnosing lumps in young women $[122,123]$.

\section{Nuclear medicine}

It is a type of molecular imaging wherever a radioactive substance (radiopharmaceutical) is introduced to an individual and the radiation from the radiopharmaceutical is displayed by perceptive emission detectors including gamma cameras and PET detectors and gamma Cameras located exterior to the body of patient. Combination of $\mathrm{CT}$ and gamma camera and the combination of CT and $\mathrm{PET}$ is a main progress in enhancing recognition and vicinity of disease.

\section{Single photon emission computerised tomography (SPECT)}

This procedure utilizes solitary photon radionuclides including gallium-67, iodine-131 and technicium-99 m that discharge gamma rays. It is a efficient scan and is precise for organ of curiosity. It can also be employed to the entire body, is comparatively secure in expressions of radiation quantity and is fine in recognition of primary and metastatic cancers. Iodine- 131 is together indicative and remedial for cancer of thyroid [124].

\section{Positron emission tomography (PET/CT)}

In expressions of radiation quantity, PET/CT is also comparatively secure and utilizes positron emitting radionuclides including oxygen-15, flouoride- 18 and carbon-11. The frequently utilized tracer in positron emission tomography is a radioactive type of glucose such as [18F]fluoro-2-deoxy-D-glucose. Tissues with enhanced metabolic requirements including developing cancer cells, demonstrate increased uptake of the tracer and displays on the scan. With combination of $\mathrm{CT}$ and PET, significant information regarding numerous situations affecting the different organs of the body is simply mapped. PET/CT is extremely perceptive and precise for predicating occult and different areas of loco-regional lymph nodal extent and/or far-away metastases not obvious by regular imaging, therefore altering staging in up to $25 \%$ of the patients. This procedure is employed for the management planning by describing spread of primary illness. It is also employed in re-staging after management ailment relapse and treatment follow up [125].

\section{Tumor markers}

Porika et al. [126] stated that tumour markers should be measured in all stages of the breast cancer including metastasis prediction, treatment, diagnosis and screening. Thirteen verities of tumor markers of breast cancer are measured, six out of 13 are novel for the guideline. The different varieties displayed proof of clinical use and are suggested for utilization in practice [127]. It is particularly significant that the comparative autonomy of the markers in reference to other accessible markers to demonstrated so as to evade the gratuitous price and expenditure of redundancy [128]. Furthermore, it is significant that the physician be attentive of the restrictions in together specificity and sensitivity of every marker so because not to specificity and sensitivity of every marker so since not to over- or under-interpret the prognostic worth of a few investigation. With these caveats in intelligence, trial submission of tissue, germ-line and soluble tumor markers can recover medical care of individuals at threat for and with breast cancer.

\section{Ca 15-3}

It can be employed for monitoring of patients with breast cancer. High blood levels are seen in $<10 \%$ of patients in the beginning of breast cancer and in approximately $70 \%$ of patients with advanced stage of breast cancer. The levels of CA 15-3 typically fall after successful management. However CA 15-3 can also be high in other types of cancers and in few non-cancerous conditions including hepatitis and benign breast conditions.

\section{Ca 27.29}

It is another marker for monitoring of patients with breast cancer. This test does not seem to be any better to identify early or advanced stage of breast cancer. This tumor marker is seen in other types of cancers and in few non-cancerous disorders.

\section{Estrogen and progesterone receptors}

For the identification of breast cancer, breast cancer tissues are investigated for estrogen and progesterone receptors including HER2 antigen. These tests give information regarding the aggressiveness of cancer and response of certain drugs used for treatment of breast cancer. 


\section{Immunohistochemistry}

Immunohistochemistry (IHC) has grown to be an essential component of pathology. Although eosin and hematoxylin stain is the primary foundation for diagnostic pathology of the breast, Immunohistochemistry stains give valuable and sometimes very important information. Furthermore, taking into consideration the part of hormonal treatment in hormone receptor-positive breast tumors, as well as the accessibility of targeted chemotherapeutic drugs for HER2-positive patients, Immunohistochemistry knowledge indicates a key element of workups. Careful use of Immunohistochemistry stains in combination with $\mathrm{E} \& \mathrm{H}$ test assists determine mainly diagnostic matters encountered by clinicians during their routine practice. Clinicians should be well-known to utilize the each immunostain and its restrictions to evade errors in interpretation. Immunohistochemistry stains assists in differential diagnosis of challenging epithelial disorders of the breast. They should be selectively and sensibly utilized and their results must be understood with the differential diagnoses in consideration and with an understanding of potential drawback [129].

\section{MRI and breast cancer}

Mammography has been considered as an appropriate screening method for breast cancer detection for many years [130] but it can't distinguish between the solid and cystic masses and can miss up to $10-15 \%$ of the cases however MRI provides more accurate results and clear benefit to the women who are developing breast cancer due to the BRCA1 and BRAC2 genetic mutation and are present with the axillary lymph adenopathy [131].

\section{Breast biopsy}

Breast biopsy is the simply best technique for diagnosing breast cancer [132]. There are numerous different types of breast biopsies. To enhance diagnostic precision and get rid of as many false negative results as possible, breast imaging, clinical breast examination and biopsy are performed concurrently (triple test).

\section{Fine needle aspiration}

A thin prickle is employed to get cells from the abnormal area or a breast lump [133]. Ultrasound can be used to assist direct the prickle. A restricted anesthetic might be used to anesthetize the region where the prickle will be inserted [134].

\section{Core biopsy}

A wider prickle is to get a portion of tissue (a core) from the abnormal area or breast lump [135]. It is typically made under restricted anesthetic, thus breast is insensitive, while patient may experience little hurt or uneasiness at what time the anesthetic is given [136]. MRI, ultrasound and mammogram can be used to guide the prickle for the duration of core biopsy [137].

\section{Vacuum-assisted stereotactic core biopsy}

In this core biopsy, different tiny tissue samples are taken via single tiny incision in the skin with a prickle and a suction-type device [138]. It is carried out using local anaesthetic. MRI, ultrasound or a mammogram may be employed to direct the prickle into position. The patient may experience little uneasiness during the process [139].

\section{Surgical biopsy}

If the abnormal vicinity is too minute to be biopsied by another procedure or the biopsy outcome is not apparent, a surgical biopsy is carried out. Prior to the biopsy, a guide wire may be placed into the breast to assist the medical doctor locate the abnormal tissue. Local anesthetic can be used and the physician may use MRI, ultrasound and mammogram to direct the wire into position. The biopsy is after that carried out under a general anesthetic. Little area close to breast tissue and lump are detached, alongside the wire [140, 141].

\section{Digital mammography}

It helps to find lumps in dense tissue. The image can also be easily stored and transmitted to another radiologist for a second opinion [142-144]. Tarhan et al. [12] stated mammography may give false negative and false positive results in patients with dense breast tissues. Kanaga et al. [145] stated that the practice of mammography is $19 \%$ in Malaysian women as compared to other study which was $10.5 \%$. Lack of health insurance coverage, low income and embracement were the main barriers to mammography as mentioned in earlier studies. Mammography is considered as the gold standard test for early detection of breast cancer [146] but in case of scarce resources in some areas in breast health awareness program should be promoted for the early detection of breast cancers and the staff should also gets the training of clinical breast examination so that the patient get diagnosed at earlier stage especially in those areas where mammography is unavailable [147].

\section{PEM and MRI in breast cancer patients}

Hence both the positron emission mammography and magnetic resonance imaging have proven breast cancer detection sensitivity, however hormone replacement therapy, post menopausal status and breast tissue density has no influence on the sensitivity of PEM and MRI. Positron emission mammography can be used as an alternative of MRI in patients who don't want to have an MRI due to multiple reasons such as time issues, limited 
budgets, lack of interest, claustrophobia (fear of being kept in as small space) [148]. However, both have the similar sensitivity to detect cancerous lesions comprehending invasive and ductal carcinoma in SITU [149].

\section{Treatment}

In the management of breast cancer, aim is to preserve quality of life with prolonged life expectancy. The use of bioflavonoids may inhibit estrogen formation [150]. Effective communication between doctors and patients plays an important role to improve clinical outcome. Oshima et al. [151] reported that effective communication between doctors and patients is effective. A study conducted in Japan indicates that this communication helps the patients to cope with adverse effects. Doctor patient communication enhances the quality of life of breast cancer patients [152]. Previous studies have shown that less exposure from radiations, higher family monthly income, long years after diagnosis, higher education, initial stage cancer and younger age were considerably related with better quality of life (QOL) in patients with breast cancer [153]. Breast cancer is less common in breast feeding women, but the protective effect of this factor is not clearly investigated [154]. Cancer is a fatal disease affecting humankind in every country. Vinblastine and vincristine was introduced in 1961 as anti cancer drugs. CIPLA has improved the process of isolating vinblastine and vincristine in the World [155], and India is exporting these alkaloids to European countries and the demand is steadily increasing. The main forms of treatment for cancer in humans are surgery, radiation and chemotherapeutic agents. The drugs can often provide temporary relief of symptoms, lengthening of life and occasionally cures the disease. Many hundreds of chemical drugs of known classes of cancer chemotherapeutic agents have been synthesized [156]. The activity of these compounds is based on their capacity for biological alkylation. The effective dose of such alkylating agents was almost the same as the toxic dose. Multi-targeted therapy could be more effective, because the recurrence rate of cancer is high and death occurs due to metastasis. Deng et al. [157] reported that Pemetrexed and Lobaplatin is prescribed in metastatic breast cancer. Huang and Cao [158] reported that cantharidin sodium injection is effective in the management of breast cancer. Cantharidinate sodium injection is herbal origin and is prepared in China for treatment of breast cancer. Breast cancer management strategies differ depending on the step of the cancer-its mass, place, whether it has extended to other organs of the body and the physical condition of the individual. Present management for breast cancer includes targeted therapies, hormonal treatment, radiation therapy and surgery.

\section{Psychological adjustment to breast cancer}

Breast cancer is extremely common and very worrying experience for numerous females every year in developing and developed countries [159]. Psychological research has given an image of the emotional and community impact of breast cancer on females' lives, and of factors linked with better versus worse amendment. Psychosocial mediations have been helpful in reducing patients' grief and improving their life quality. Current study also recommends that psychological aspects might be associated with potentially significant biological ailment linked processes. Additionally, to giving an idea of the psychological aspects in breast cancer, investigation in this vicinity has given a foundation for further studies on adjustment to health-related nervous tension in common [160].

\section{Surgery}

This is the foremost management strategy for individuals whose breast cancer has not extended to further areas of the body and is also a choice for further complex stages of the illness [161-163]. The kinds of breast cancer surgery vary in the quantity of tissue that is excised with the cancer; this depends on the cancer's characteristics, whether it has extended, and the patient's special feelings. A few of the most familiar kinds of surgery include:

\section{Lumpectomy (breast conserving surgery)}

Some patients diagnosed with breast cancer undergo some type of surgery [164]. According to American cancer society, lumpectomy or partial mastectomy is the procedure of removing the part of the breast that contains malignant tumor along with some healthy tissues and surrounding lymph nodes leaving the major part of the breast intact as possible [165]. This practice generally experienced in women that are in their initial phase of cancer, however the patient also requires another type of treatment such as radiation therapy, chemotherapy or hormone replacement therapy along with this procedure. Most surgeons and patients prefer lumpectomy initially rather than having the complete breast removal, especially if the patient is more concerned about losing her breast [166]. However, adverse effects of lumpectomy are tenderness, temporary inflammation, sclerosis and changed appearance of breast, etc [167].

\section{Mastectomy}

Mastectomy is done to decrease the risk of development of breast cancer [168]. Bilateral prophylactic mastectomy decreases the chances of development of breast cancer but does not eliminate the risk of developing cancer completely [169]. Aromatase and tamoxifen decreases the risk of contra-lateral breast cancer and it is considered 
more effective than contra lateral prophylactic mastectomy [170]. Mastectomy is considered the most effective method of dealing with an already diffused case of breast cancer, for which a lumpectomy was not decisive enough. Nevertheless, the loss of breast leads to feeling of asexuality and loss of self-image and consequent depression in most women [171].

\section{Reconstructive surgery}

Females who have a mastectomy might as well have breast renovation, either immediate reconstruction or delayed reconstruction. It is performed to get better the look of the breast following tumor surgery. All females having a mastectomy must be presented the option to converse reconstructive surgical treatment [172]. Mastectomy is a comparatively simple surgical practice that typically results in stay in hospital for 1-2 days. Deficiency of the breast mass changes the patient's special look and can create wearing a few forms of clothing difficult. The utilization of an exterior prosthesis to tackle these problems can be awkward and scratchy, particularly for females with huge breasts. Though, the most significant issue of mastectomy is the psychosocial effect of the physical and aesthetic distortion, which can comprise nervousness, sadness, and negative impacts on body figure and on sexual activity [173]. Breast reconstruction is commonly requested by females with breast cancer who are unable for breast-conserving treatment and females with an increased hereditary danger for breast cancer. Existing breast reconstruction procedures are miscellaneous and might engage the utilization of prosthetic implant or an autologous tissue flap, or both. Despite of the method employed, cancer might relapse in the reconstructed breast; additionally, in autologous tissue flaps reconstructed breasts, little complexity such as fat necrosis may take place. Researches recommend that breast reconstruction restores body representation, proves vigor, femaleness, and sexuality; and optimistically influences the patient's feelings of comfort and life quality [174].

\section{Ovarian ablation as adjuvant therapy for breast cancer}

Ovarian ablation has been employed as management for breast cancer [175]. There are numerous techniques of ovarian ablation such as radiation induced ablation, surgical removal of ovaries and chronic utilization of luteinizing hormone-releasing hormone (LHRH) analogs. Additionally, there are few proposals that cytotoxic chemotherapy might perform by inducing ovarian ablation in premenopausal females with breast cancer. Of the abundant case series and clinical studies of ovarian ablation conducted in the earlier period, numerous have been laden with methodologic issues. Meta-analysis of randomized clinical studies demonstrates a momentous enhancement in overall survival and disease-free survival for females whose ovarian ablation were performed as adjuvant treatment compared to those females who did not. Literature review indicates that ovarian ablation may be employed an alternative therapy for breast cancer [176].

\section{Role of estrogen and progesterone receptors in the management of breast cancer}

The estrogen receptor assay has developed into a typical practice in the treatment of complex breast cancer [177]. Tumors missing estrogen receptor react occasionally to endocrine treatment, while improvement proportions of $50-60 \%$ are seen in estrogen receptor positive tumors. Current researches demonstrate that the estrogen receptor condition of the principal cancer is a superior interpreter of the endocrine reliance of metastatic cancers at the moment of clinical deterioration. Additionally, the deficiency of estrogen receptor in the primary cancer is an significant self-regulating predictive display of higher incidence of relapse and shorter survival. Quantitative investigation of estrogen receptor and an analysis for progesterone receptor are two procedures for enhancing the precision of selecting or rejecting individuals for hormonal treatment; cancers with a elevated quantitative estrogen receptor amount or those with a positive progesterone receptor show the maximum response. Initial investigation demonstrates that the existence of progesterone receptor might be a improved indicator of tumor hormone dependence than quantitative estrogen receptor [178].

\section{Anti-estrogen therapy}

It can be used in such types of cancers that are affected by hormones and the tumor has hormone receptors such as estrogen receptors. Clarke et al. [179] stated that the most common category of drugs that are used in breast cancer is anti estrogen, which includes the agents that are (tamoxifen, raloxifene, toremifene etc). Tamoxifen inhibits the hormone oestrogen from entering into cells of the breast cancer. This mechanism inhibits the breast cancer cells from developing. Tamoxifen can be suggested to treat female of any age group. However tamoxifen is considered as the drug of choice in women that have positive estrogen receptor breast carcinoma. Tamoxifen is a selective estrogen receptor modulator (SERMS) and acts like estrogen on other parts of the body such as uterus. However, it demonstrates anti estrogen properties of breast tissues and competes with estrogen for binding to the estrogen receptors in the breast [180]. If we have to discuss about the toxic effects of anti estrogen therapy, comparatively there is very least toxicity 
found in it as compared to other cytotoxic drugs [181]. While some patients withdraw the treatment before completing the course of drug due to the side effects such as hot flushes, gastro intestinal problems and vaginitis etc. Though, the medical indications for discontinuing antiestrogen therapy include adeno carcinoma, sarcoma and thrombo embolic diseases etc. Any how the American society of clinical oncology recommends Tamoxifen as standard adjuvant therapy for patients with Estrogen positive breast carcinoma [182]. On the other hand Fulvestrant; Faslodex has entirely anti estrogenic action and is considered as estrogen antagonist it demonstrates anti neo plastic activities in breast tissues without having a positive effect on the uterus and bones, which may lead to certain side effects if taken for a long period of time such as osteoporosis [183]. Tamoxifen and raloxifene are selective estrogen receptor modulators (SERMs), a set of medicine that selectively prevents or motivates oestrogen-like activity in different tissues, affecting the estrogen receptors [184]. Tamoxifen exhibits its oestrogen antagonist action in numerous tissues such as uterus, liver, bone and breast [185]. It was used as adjuvant treatment in estrogen receptor positive patients and tamoxifen was accepted by the United States Food and Drug Administration (FDA) in 1998 for the impediment of breast cancer for females at elevated danger [186]. This verdict was based on the outcome of a experiment carried out by the United States National Cancer Institute that was interrupted premature as an intervening study indicated that tamoxifen decreased breast cancer prevalence by approximately one half $[187,188]$. Four big prospective studies have investigated the efficacy of tamoxifen versus placebo for breast cancer danger decline for females at elevated danger of breast cancer [189]. A summary of these studies demonstrated a $38 \%$ general decline in breast cancer occurrence for females at increased danger of breast cancer who administered tamoxifen for the period of 5 years and also indicated that tamoxifen inhibits only estrogen receptor positive breast cancers $(\mathrm{RR} \sim 50 \%)$ with no influence on estrogen receptor negative breast cancer [190]. A variety of adverse effects have been reported for females taking tamoxifen, such as venous thrombosis, cataract, endometrial cancer, menstrual disorders and hot flushes. A study indicated that the risk decreasing activity of tamoxifen expands beyond the vigorous management phase of 5 years, and remains for minimum 10 years, whereas the majority of adverse reactions do not carry on behind the 5 year management duration [191]. Raloxifene, has also been revealed to decrease danger of breast cancer, however seems to exert some adverse reactions [192]. During the precedent periods, clinical studies carried out to investigated the efficacy of raloxifen on fracture and osteoporosis, showed a 44-76\% risk decline of breast cancer prevalence in the raloxifen treated patients as compared to the placebo group [193]. A randomized clinical study of Raloxifen and Tamoxifen was planned for comparing the efficacies of raloxifen and tamoxifen on postmenopausal females with an enhanced 5-year threat of breast cancer as expected by the Gail model $[194,189]$. The study demonstrated that raloxifen was comparable to the tamoxifen in decreasing the threat of invasive breast cancer and was linked with a minor danger of cataract and thromboembolism than tamoxifen. In 2007, approximately 10 years following the endorsement of tamoxifen, the FDA permitted raloxifen for the impediment of breast cancer for postmenopausal females with osteoporosis and for postmenopausal females at increased danger for breast cancer. In Australia, tamoxifen is prescribed for the treatment of breast cancer and osteoporosis.

\section{Aromatase inhibitors}

These are compound designed for decreasing oestrogen formation by targeting aromatase, the enzyme complex accountable for the last stair in the formation of estrogen [195]. The third-generation aromatase inhibitors including letrozole, exemastane and anastrozole are in present utilization [196]. Randomized clinical trial conducted for investigation of these agents in the treatment of breast cancer has indicated that these compounds contain an outstanding effectiveness in treating females with advanced disorder. Clinical study indicated that females managed with aromatase inhibitors had a superior contra lateral breast cancer threat decline than females managed with tamoxifen [131].

\section{Radiation therapy}

It is useful for reducing the necessity of mastectomies. A combination of a lumpectomy and radiation therapy is being increasingly used over a mastectomy in the early stages of breast cancer [197]. A study was conducted in India. For this study 135 women were selected, most of them had undergone mastectomy. At the time of analysis, there was no local recurrence after hypo fractioned radiation therapy and metastatic disease developed in only four patients [198]. Zhou et al. [199] reported that radiation therapy is effective in early breast cancer patients. This study was conducted on 143 women who underwent either routine or intra operative radiation therapy after breast conserving surgery. At 54 months of follow up, there was a significant local control of the tumour. Highenergy rays from radiation therapy kill cancer cells. This therapy affects only the cells that are treated. Use of radiation therapy may be done after breast cancer surgery to destroy the remaining cells in the chest area. 


\section{Brachytherapy}

It is a kind of radiotherapy [200]. It might be recognized as accelerated partial breast irradiation. It directs radiation merely to the area around the vicinity wherever the cancer was. This might replace the requirement to provide radiation to the whole breast. It also decreases the number of management sessions [201].

\section{Chemotherapy}

The process of killing cancer cells by using certain medicines is termed as chemotherapy [202, 203]. It can be given in both situations, before and after surgery, depending upon the condition of the patient. According to the American cancer society the medicines include in chemotherapy are Docetaxel, Paclitaxel, Platinum agents (cisplatin, carboplatin), Vinorelbine (Navelbine), Capecitabine (Xeloda), Liposomal doxorubicin (Doxil), Cyclophosphamide (Cytoxan), Carboplatin (Paraplatin) etc [204]. However it has various side effects [205]. Metastatic or secondary breast can is difficult to treat but it can be controlled and sometime for various years [206]. Chemotherapy can be prescribed to manage metastatic breast cancer to minimize or sluggish its development. It can also be administered to decrease some manifestations. Other treatment option can be initiated prior or alongside chemotherapy.

\section{Taxol}

Taxol is used clinically in the treatment of ovarian cancers and is undergoing clinical trials against metastatic breast cancers [207]. It may also have potential value for lung, head and neck cancers. Taxotere is a side chain analogue of taxol, which has also been produced by semi synthesis from 10-deacetyl-baccatin III [208]. It has improved water solubility, and is being clinically tested against ovarian, and breast cancers. It can be used in those where resistance to cisplatin has been observed [209].

\section{Anthracyclines}

Anthracycline are commonly prescribed in the treatment of breast cancer [210]. They impede with enzymes associated the DNA copying, which is desired for cells to separate to create new cells. Epirubicin and doxorubicin are the most commonly used medicines in breast cancers. There is proof that anthracyclines functions better than various other chemotherapy medicines [211]. However these have adverse reactions such as damage to the heart and loss of hair $[212,213]$. Prior to start of medicines, patient should converse with clinician any probable adverse reactions of drugs used and how these medicines might influence life quality.

\section{Thermochemotherapy}

Medifocus heat management in combination with chemotherapy enhanced the shrinkage of median cancer in the thermochemotherapy arm to $88.4 \%$, whereas for chemotherapy alone the shrinkage of median cancer was $58.8 \%$. For the thermo-chemotherapy management arm, approximately $80 \%$ of breast cancers had a cancer size decrease of $80 \%$ or more, compared to merely $20 \%$ for the chemotherapy alone [214].

\section{Complementary therapies}

Women with breast cancer occasionally desire to use complementary therapies along with their medical therapy [215]. These therapies are usually not investigated in randomized clinical trials [216]. Some female believe that they have benefited from a number of these treatments [217]. Vitamins, nutritional supplements, yoga, meditation, visualization, traditional medicines and acupuncture are included in complementary therapies.

\section{Medicinal plants \\ Medicinal plants}

Screening of plant extracts for anticancer activity started in 1961 by National cancer institute in the USA, and up to 1981 (20 years) about 1,14,045 plants had been screened of which only $3.4 \%$ (representing about 3400 different species) have been observed to be active in one or more biological systems.

\section{Ganoderma lucidum (Polyporaceae)}

It contains ganoderic acid, ganoderic acid G, ergosta, ergosterol peroxide ganoderic acid G, ergosta, ergosterol peroxide, methyl ganoderate $\mathrm{A}, \mathrm{B}$, ganoderic acid $\mathrm{C} 2$. It is an anticancer [218]. Jiang et al. [219] reported that the Ganoderma lucidum suppresses growth of breast cancer cells through the inhibition of Akt/NF-kappa B signaling. It is used to treat cancer cells. It inhibits the transcription factor NF-kappa B and inhibits the invasive behavior of breast cancer cells. The exact mechanism for inhibition of cancer cells is not understood. The study showed that the proliferation of breast cancer MDA-MB-231 cells is inhibited and Akt/NF-kappa B signaling is suppressed. Phosphorylation of Akt at Ser473 is suppressed by this plant and expression of Akt is suppressed, as a result NFkappa B activity in MDA-MB-231 cells is inhibited.

\section{Momordica charantia (Cucurbitaceae)}

The parts used are fruits, leaves and seeds. It contains glucoside, albuminoids, fatty acids, non polar lipid, linolinic acid, palmitic acid, myrtenol, hexenol, benzyl alcohol, acylglycosylsterols and glycoproteins [220]. It is hepatoprotective, tonic, stimulant, emetic, laxative, stomachic and cancer [221]. It is used to treat gout and 
rheumatism. Ray et al. [222] reported that Momordica charantia extract inhibits breast cancer by modulating cell cycle regulatory genes. This study was conducted in vitro models. An extract of this plant was investigated in human breast cancer cells, MCF-7 and MDA-MB-231, and primary human mammary epithelial cells. This extract was able to decrease cell proliferation and apoptotic cell death was induced. Survivin and claspin expression was inhibited by this extract.

\section{Carthamus tinctorius (Asteraceae)}

The parts used are flowers and seeds. It contains palmitic acid, hexadecanolenin, coumaric acid, daucosterol, apigenin, kaempferol, trans-3-tridecene-5, 7, 9, 11-tetrayne-1, 2-diol, trans-trans-3, 11-tridecadiene -5, 7, 9-triyne -1, 2-diol [223]. It is used in colds, flu, fevers, hysteria, anemia, and diabetes mellitus. It is an antioxidant [224] and alpha glucosidase inhibitor [225]. Loo et al. [226] reported the efficacy of this plant in breast cancer. MDA-MB-231 breast cancer cell and normal human mammary gland cell were treated with a compound that contains Carthamus tinctorius. This compound observed inhibition of cell proliferation. Inhibition of cell proliferation was dose dependent. Its cytotoxic activity was more than commonly used cytotoxic drugs.

\section{Viscum album (Viscaceae)}

Part used are leaves and stem. It contains sinapylflavanone, glucopyranoside, flavanone, hydroxy flavanone and viscin [227]. It is antioxidant, cardiac tonic, and anticancer [228]. It is used in palpitation, vascular spasms, asthma, dizziness, vertigo and headaches. Gunver et al. [229] reported the efficacy of this plant in breast cancer.

\section{Calendula officinalis (Asteraceae)}

The parts used are leaves. It contains triterpene, calendula glycoside, butyl ester, flavonol glycosides, and carotenoids [230]. It is anti-inflammatory and anti-cancer [231]. It is used in carcinoma of the vagina, and cervix. Pommier et al. [232] reported the efficacy of Calendula officinalis for the prevention of acute dermatitis during irradiation for breast cancer.

\section{Citrullus colocynthis (Cucurbitaceae)}

The parts used are seeds and fruit. It contains phytosterol, flavones C-glycosides, saponins, aspartic acid, arginine, colocynthin, colocynthitin and cucurbitacin glycosides [233]. It is used in constipation and carcinoma of the breast [234]. It is an emmenagogue, ecbolic, cathartic, hydragogue and antioxidant [235]. This plant has growth inhibitory activity. Cucurbitacin glucosides have been isolated from this plant. These glycosides prevent human breast cancer cells [234].

\section{Indole-3-Carbinol (13C)}

A compound known as indole-3-carbinol, which is a plant chemical derived from cruciferous vegetables such as Brussels sprouts and cabbage, changes the way estrogen is metabolized. This compound predictably alters the endogenous estrogen metabolism towards increased catechol estrogen production and may thereby provide a novel dietary means for decreasing risk of breast cancer [236].

\section{Silibinin and Chrysin}

Previous research indicates that chrysin and silibinin function synergistically and possess significant anticancer activities against T47D breast cells [187, 188]. It shows potential that the synergistic efficacy is based, at least in part, by down-regulation of hTERT and cyclin D1. Their potential activities in the established synergism among Chrysin and Silibinin should be verified by additional in vitro or in vivo researches. Study demonstrates that Chrysin and Silibinin combined might come out as an eye-catching approach based on herbal medicine for the management of breast cancer [237].

\section{Lactobacillus acidophilus}

Breast cancer and hyperestrogenism may be decreased by the inclusion of lactobacillus acidophilus in the diet. This useful bacterium helps to metabolize estrogen properly in the bowel. Clinicians can prescribe lactobacillus acidophilus that is available in different forms, including capsules in patients with breast cancer [238].

\section{Selenium}

Women with breast cancer have been shown to possess selenium levels that are lower than those of women without cancer. Selenium is a trace mineral that is often lacking in refined food diets. A contrary association exists among the prevalence of human breast cancer and concentration of dietary selenium. The adding of Selenium to the food has been revealed to reduce the occurrence of breast cancer [239].

\section{Targeted therapies}

These are drugs prescribed to manage some types of breast cancer. The mainly familiar targeted treatment is the drug Herceptin [240]. It is prescribed to manage HER2 positive breast cancer. It functions by preventing the cancer cells from developing and progressing [241].

\section{Gene therapy for carcinoma of the breast}

Gene therapy is a remedial strategy that is considered to correct particular molecular deformities associated with the progression or development of breast cancer [242]. Mutated BRCA1 and p53 genes recognized as cancer 
susceptibility gene are involved in progression of cancer [243]. Since mutational inactivation of gene activity is reserved to cancer cells in these contexts, cancer gene modification techniques may give an opening for selective targeting without major hazards of normal, noncancer cells [244, 245]. Both BRCA1 and p53 emerge to restrain tumor cells that lack mutations in these genes, indicating that the so-called gene modification techniques may contain broader efficacy than previously considered. Raising awareness of cancer genetics has recognized these and new genes as possible targets for gene substitute treatment [246]. Early patient study of BRCA1 and $\mathrm{p} 53$ gene therapy have given a number of indications of possible effectiveness, but have also recognized areas of clinical trials that are wanted prior to these therapeutic strategies may be broadly employed in patients with breast cancer [247].

\section{Oncogenes inactivation}

Numerous oncogenic proteins have been recognized and linked with a variety of cancers [248]. The frequently practical strategy in clinical studies is the employment of antisense options. Oncogenes transcription also can be prevented by means of adenoviral gene E1A, which hinder erbB-2 transcription, an option helpful in managing cancer that over express this oncogenic protein [249].

\section{Augmentation of cancer suppressor genes}

The mutations in tumor suppressor genes are linked with the development of numerous cancers. Some clinical studies are being conducted to deliver p53 via adenoviral vectors to different cancers. Likewise, viral vectors have been used to administer a breast cancer gene BRCA1 and retinoblastoma gene into ovarian cancer and bladder, correspondingly. In various circumstances, this strategy will fall short, as the mutant gene indicates dominant negative activity of the normal gene. To avoid this difficulty for p53 gene therapy, a genetic repair approach rather than a gene augmentation strategy might be more successful [250].

\section{Cancer stem-cell therapy for breast cancer}

Current investigation in biology of breast has provided the foundation for the cancer stem-cell hypothesis [251]. Two significant aspects of this theory are that cancer arises in progenitor cells or mammary stem cells as an outcome of dysregulation of the normally strongly regulated method of self-renewal. As a consequence, cancers posses and are obtained by a cellular subcomponent that keeps central stem-cell functions such as self-renewal, which directs differentiation and tumorigenesis that is responsible for cellular heterogeneity. Development in the stem-cell field have guided to the recognition of stem cells in normal and malignant tissue of the breast. The investigations of these stem cells have assisted to clarify the source of the molecular complexity of breast cancer in human. The cancer stem-cell theory has significant role for timely recognition, prevention, and management of human breast cancer. Dysregulation of stem cell renewal pathways are involved in the development of both sporadic and hereditary breast cancers. These abnormal stem cells may give targets for the improvement of cancer prevention options. In addition, since breast cancer stem cells may be extremely challenging to chemotherapy and radiation, the progress of additional efficient treatments for breast cancer may need the efficient targeting of this cell population [252].

\section{Anti-oestrogens and prevention of breast cancer}

With the accomplishment of anti-oestrogens in breast tumor management, numerous studies evaluated their use as an mediator to avert breast cancer in female at high risk [253, 254]. Tamoxifen is the antiestrogen medicine employed most commonly in the treatment of breast cancer. Administration of tamoxifen as an adjuvant treatment following surgery, normally for 5 years, decreases the risk of hormone receptor breast cancer recurrence.

Metastatic breast cancer is also managed by tamoxifen. In numerous females, tamoxifen induce the manifestations of menopause such as mood swings, vaginal discharge and hot flushes. Toremifene is one more medicine strongly related to tamoxifen. It is used an alternate drug in postmenopausal female for the treatment of metastatic breast cancer. Fulvestrant is another drug that decreases the estrogen receptor numbers. It is usually useful in postmenopausal female, even in tamoxifen resistant breast cancer. In previous studies, tamoxifen was evaluated for its efficacy in 13, 388 females at higher risk of breast cancer for the period of 5 years. The study indicated a $49 \%$ decrease in risk of increasing invasive breast cancer and as well decreased risk of opposing side breast cancer, reappearance and extended existence in the female who had tamoxifen as accessory after operation [187, 188]. Antioestrogens are currently suggested as chemoprevention for female with atypical hyperplasia, genetic tendency to develop cancer and important family history of breast tumor. They are also prescribed because component of practice post-operative concomitant management of those with estrogen receptor positive cancers for duration of 5 years following surgery [255].

\section{Human monoclonal antibody}

Monoclonal antibodies are prepared in the laboratory [256]. These are used alone or in combination with radiation therapy and chemotherapy to locate and 
target cancer cells. Usually, the body's immune system attack to foreign antigens such as infectious agents. It will then create antibodies to assist fight it off. The body does not identify cancer cells as a kind of foreign attacker. So, antibodies are then not formed. A randomized clinical trial was conducted to investigate efficacy of denosumab, a completely human monoclonal antibody against receptor activator of nuclear factor $\mathrm{k}$ $B$ (RANK) ligand, in comparison with zoledronic acid in the prevention of skeletal-related events in breast cancers individuals with bone metastases. Denosumab was found better as compared to zoledronic acid in preventing or delaying the SREs in breast cancer patients with bone metastasis. It is demonstrated that denosumab is possible therapeutic alternative for individual with bone metastases [257].

\section{Immunotherapy}

It utilizes the immune system of the body to fight against the cancer cells [258]. Cancer vaccine is one of its examples. Parts of cancer cells or cancer cells are utilized for formation of vaccines. These cells excite the body's immune system to assist assault and destroy cancer cells [259]. Immunotherapy has turn into a significant constituent in the management of breast cancer. HER2 targeted treatment are at the present an important part of HER2 over expressing breast tumor therapy. Trastuzumab, with the new current accompaniments of pertuzumab and TDM1, encompass considerably superior breast cancer prediction. With various Federal Drug and Administration recommended antibody treatments used in together the adjuvant and metastatic settings, development progresses to be done in the area of immunotherapies. Current achievements in targeted therapies, vigorous particular immunotherapy, grasp assure for continuous success in general endurance within the adjuvant setting. The extremely precise and targeted strategy of vaccine therapy not simply avoids the adverse effects of recent standard of care therapies, active and passive immunotherapies including ipilimumab; however presents remedial strategy beyond now the HER2-overexpressing individuals. Even though vaccines for breast cancers have been mainly ineffective in precedent clinical studies, the most of these studies conducted in the location of latestage metastatic illness, adverse surroundings for agents intended to stop, as different to manage, disease. With present clinical studies conducted on the adjuvant settings, immunogenicity is at the present indicating association with medical response.

\section{Anti-angiogenesis drugs}

Angiogenesis and inflammation are host-dependent manifestations of tumors that can be targeted with impediment strategies long prior to cancer start and develop [260]. Numerous prescription and non-prescription medicines are now accessible for utilization in angioprevention. Angioprevention can be proposed at four levels; first for the healthy people, 2nd for population at enhanced risk of tumor, 3rd for preneoplastic disease and 4th for prevention of cancer relapse. There are numerous achievements in prevention of cancer that reveal medical possibility and levels of interference, from no to slight to strong clinician participation. To evade toxicity whereas maintaining effectiveness, angioprevention desires to attain a level of angiogenesis prevention that is not extremely oppressive, such that hale and hearty vascular activity is maintained. These drugs block angiogenesis. In the absence of blood supply to cancer cells, they cannot develop and die. Various drugs are under investigation for the management of metastatic breast cancer. In initial stage of breast cancer, they are also investigate in the neoadjuvant (before surgery) setting [261]. Antiangiogenic treatment in breast cancer presents important promise, and numerous continuing investigations are trying to better describe the best management settings and mediator assortment. For patients with estrogen receptor positive aliment, researches recommend a relationship among resistance of endocrine and cancer dependence on angiogenic networks, suggesting a possible curative advantage in mixing endocrine treatment with antiVEGF mediator. Findings from randomized clinical studies emphasize the multiplicity in reaction to antiVEGF treatment and recommend the requirement for better choice of patient subsets further to be expected to advantage from these therapies. The recognition of biomarkers for therapy response is solitary part of deep attention, though mainly study to date has become unsuccessful to discover a relationship linking cancer-associated markers including cancer mutations and EGF expression and scientific response.

\section{Surveillance and follow up}

A regular assessment of the important in print literature conducted by de Bock et al. [262], revealed that $40 \%$ of recurring cancers are identified in asymptomatic individuals during routine visits. This information intensifies the significance of surveillance and follow-up. Clinical investigation such as history and physical examination is suggested each 4-6 months for 5 years, after that each year with annual mammography. Female on tamoxifen should go through a yearly gynecologic evaluation if the uterus exists. Female who suffers from ovarian failure secondary to management or on an aromatase inhibitor should have checking of bone fitness with a bone mineral thickness determination at the start and sometimes subsequently. Women should also be advised to adopt variable risk 
factors, including lessening alcohol use, reducing BMI and enhancing physical activity.

\section{Conclusion}

The increase of information on the pathophysiologic mechanisms of breast cancer has brought extensive development in the figure of biomolecular markers. In addition, the development of targeted drug design has grown quickly and more complicated, providing numerous agents that target these markers for in vivo investigation in animal models as well as clinical studies. The enthusiasm among scientists and Physicians about the growing management strategies is tempered by apprehension that resources are insufficient to carry the mainstream of these agents to advanced clinical trials. The challenges, then, are to choose the most capable agents to be investigated and the proper clinical studies for such evaluations. We have adopted a justifying strategy to unfolding the most extensively documented molecular targets in breast cancer. Drugs that amend the NRF have not been evaluated comprehensively so far, and such studies can boost the chances for true 'endocrine' strategies for management of breast cancer. Furthermore, agents that amend angiogenesis and apoptosis demonstrate an thrilling area of research, mostly in vigilantly chosen combination regimens.

\section{Authors' contributions}

MA provided concept and design of the manuscript. MI wrote the draft of Manuscript. MD and AUK revised the manuscript. All authors read and approved the final manuscript.

\section{Author details \\ ${ }^{1}$ Department of Eastern Medicine and Surgery, Directorate of Medical Sciences, GC University Faisalabad, Old Campus, Allam lqbal Road, Faisal- abad 38000, Pakistan. ${ }^{2}$ Faculty of Eastern Medicine, Hamdard University Kara- chi, Main Campus, Sharea Madinat al-Hikmah, Mohammad Bin Qasim Avenue, Karachi 74600 , Sindh, Pakistan. ${ }^{3}$ Laboratory of Neuroanatomy \& Neuropsycho- biology, Department of Pharmacology, RibeirãoPreto Medical School of the University of São Paulo, AV. Bandeirantes, 3900, RibeirãoPreto, 14049-900 São Paulo, Brazil. ${ }^{4}$ Department of Eastern Medicine and Surgery, School of Medical and Health Sciences, University of Poonch Rawalakot, Hajira Road, Shamsabad, Rawalakot 12350, Azad Jammu and Kashmir, Pakistan.}

\section{Acknowledgements}

Not applicable.

\section{Competing interests}

The authors declare that they have no competing interests.

\section{Availability of data and materials}

Not applicable.

\section{Consent for publication \\ Not applicable.}

Ethics approval and consent to participate

Not applicable.

\section{Funding}

No funding received from any source.

\section{Publisher's Note}

Springer Nature remains neutral with regard to jurisdictional claims in published maps and institutional affiliations.

Received: 15 July 2017 Accepted: 22 September 2017

Published online: 02 October 2017

\section{References}

1. Coleman M, Quaresma M, Berrino F, Lutz JM, Angelis R, Capocaccia R, et al. Cancer survival in five continents: a worldwide population-based study (CONCORD). Lancet Oncol. 2008;9:730-56.

2. Anderson B, Yip C, Smith R, Shyyan R, Sener S, Eniu A, et al. Guideline implementation for breast healthcare in low-income and middleincome countries: overview of the breast health global initiative global summit 2007. Cancer. 2008;113:2221-43.

3. Siegel R, Naishadham D, Jemal A. Cancer statistics, 2013. CA Cancer J Clin. 2013;63:11-30.

4. Berry D, Cronin K, Plevritis S, Fryback D, Clarke L, Zelen M, et al. Effect of screening and adjuvant therapy on mortality from breast cancer. N Engl J Med. 2005;353:1784-92.

5. Peng J, Sengupta S, Jordan VC. Potential of selective estrogen receptor modulators as treatments and preventives of breast cancer. Anti-Cancer Agents Med Chem. 2009;9:481-99.

6. Reeder J, Vogel V. Breast cancer prevention. Cancer Treat Res. 2008;141:149-64.

7. Abdull R, Noor N. Cruciferous vegetables: dietary phytochemicals for cancer prevention. Asian Pac J Cancer Prev. 2013;14:1565-70.

8. Dwivedi V, Shrivastava R, Hussain S. Comparative anticancer potential of clove (Syzygium aromaticum) —an Indian spice — against cancer cell lines of various anatomical origin. Asian Pac J Cancer Prev. 2011;12(8):1989-93.

9. Mary J, Vinotha P, Pradeep A. Screening for in vitro cytotoxic activity of seaweed, Sargassum sp. against Hep-2 and MCF-7 cancer cell lines. Asian Pac J Cancer Prev. 2012;13:6073-6.

10. Mukherjee P, Wahile A. Integrated approaches towards drug development from Ayurveda and other Indian system of medicines. J Ethnopharmacol. 2006;103:25-35.

11. Zhu Y, Zhou L, Jiao S, Xu L. Relationship between soy food intake and breast cancer in China. Asian Pac J Cancer Prev. 2011;12:2837-40.

12. Han S, Guo Q, Wang T. Prognostic significance of interactions between ER alpha and ER beta and lymph node status in breast cancer cases. Asian Pac J Cancer Prev. 2013;14:6081-4.

13. Ferlay J, Soerjomataram I, Ervik M. Cancer incidence and mortality worldwide: sources, methods and major patterns in GLOBOCAN 2012. Int J Cancer. 2015;136:359-86.

14. Agnieszka M, Magdalena K, Grazyna J, Iwanowicz P. Assessment of midwifery student preparation for erforming the role of breast cancer educator. Asian Pac J Cancer Prev. 2014;15:5633-8.

15. Haghighat S, Akbari M, Ghaffari S, Yavari P. Standardized breast cancer mortality rate compared to the general female population of Iran. Asian Pac J Cancer Prev. 2012;13:5525-8.

16. Bhurgri Y. Karachi cancer registry data implications for the national cancer control program of Pakistan. Asian Pac J Cancer Prev. 2004;5:77-82.

17. Hanif M, Zaidi P, Kamal S, Hameed A. Institution-based cancer incidence in a local population in Pakistan: 9 year data analysis. Asian Pac J Cancer Prev. 2009;10:227-30.

18. Khoker S, Muhammad U, Masooma R, Naseem A, Afaf S. Clinico-pathologic profile of breast cancer patients in Pakistan: 10 years data of a local cancer hospital. Asian Pac J Cancer Prev. 2012;13:693-8.

19. Badar F, Faruqui Z, Uddin N. Management of breast lesions by breast physicians in a heavily populated south Asian developing country. Asian Pac J Cancer Prev. 2011;12:827-32.

20. Moore M, Ariyaratne Y, Badar F. Cancer epidemiology in South Asia past, present and future. Asian Pac J Cancer Prev. 2009;10:49-67.

21. Jamal S, Mamoon N, Mushtaq S, Luqman M. Carcinoma of the male breast: a study of 141 cases from Northern Pakistan. Asian Pac J Cancer Prev. 2006;7:119-21. 
22. Yang L, Parkin D, Ferlay J. Estimates of cancer incidence in China for 2000 and projections for 2005. Cancer Epidemiol Biomarkers Prev. 2005; $14: 243-50$

23. Torre LA, Sauer AM, Chen MS, Kagawa-Singer M, Jemal A, Siegel RL. Cancer statistics for Asian Americans, native hawaiians, and pacific islanders, 2016: converging incidence in males and females. Cancer J Clin. 2016;66:182-202.

24. Aronson K, Miller A, Woolcott C, Sterns E, McCready D, Lickley L, et al. Breast adipose tissue concentrations of polychlorinated biphenyls and other organochlorines and breast cancer risk. Cancer Epidemiol Prev Biomarkers. 2000;9:55-63.

25. Stark G, Grandel S, Spilker G. Tissue suction of the male and female breast. Aesth Plast Surg. 1992;16:317-24.

26. Tanis P, Nieweg O, Olmos R, Kroon B. Anatomy and physiology of lymphatic drainage of the breast from the perspective of sentinel node biopsy1. J Amer Coll Surg. 2001;192:399-409.

27. Thomsen S, Tatman D. Physiological and pathological factors of human breast disease that can influence optical diagnosis. Ann N Y Acad Sci. 1998:838(1):171-93.

28. Jagannathan N, Sharma U. Breast tissue metabolism by magnetic resonance spectroscopy. Metabolites. 2017;7:25-30.

29. Brayboy L, Oulhen N, Long S, Voigt N, Raker C, Wessel G. Multidrug resistance transporter-1 and breast cancer resistance protein protect against ovarian toxicity, and are essential in ovarian physiology. Rep Toxicol. 2017;69:121-31.

30. Hassiotou F, Geddes D. Anatomy of the human mammary gland: current status of knowledge. Clin Anat. 2013;26:29-48.

31. Love RR, Love SM, Laudico AV. Breast cancer from a public health perspective. Breast J. 2004;10:136-40.

32. West A, Wullkopf L, Christensen A, Leijnse N, Tarp JM, Mathiesen J, et al. Division induced dynamics in non-Invasive and invasive breast cancer. Biophys J. 2017;112:123-5.

33. Posner MC, Wolmark N. Non-invasive breast carcinoma. Breast Cancer Res Treat. 1992;21(3):155-64.

34. Hang J, Sim L, Zakaria Z. Non-invasive breast cancer assessment using magnetic induction spectroscopy technique. Int J Integr Eng. 2017:9:15-20.

35. Inoue M, Nakagomi H, Nakada H, Furuya K, Ikegame K, Watanabe H. Specific sites of metastases in invasive lobular carcinoma: a retrospective cohort study of metastatic breast cancer. Breast Cancer. 2017;20:1-6.

36. Clauser P, Marino MA, Baltzer PA, Bazzocchi M, Zuiani C. Management of atypical lobular hyperplasia, atypical ductal hyperplasia, and lobular carcinoma in situ. Exp Rev Anticancer ther. 2016;16:335-6.

37. Chuba P, Hamre M, Yap J, Severson R, Lucas D, Shamsa F. Bilateral risk for subsequent breast cancer after lobular carcinoma-in-situ: analysis of surveillance, epidemiology, and end results data. J Clin Oncol. 2005:23:5534-41.

38. Nakhlis F, Morrow M. Ductal carcinoma in situ. Surg Clin 2003:83:821-39.

39. Harris LN, Ismaila N, McShane LM, Andre F, Collyar DE, Gonzalez-Angulo AM, et al. Use of biomarkers to guide decisions on adjuvant systemic therapy for women with early-stage invasive breast cancer. J Clin Oncol. 2016;34:1134-50

40. Ziperstein MJ, Guzman A, Kaufman LJ. Evaluating breast cancer cell morphology as a predictor of invasive capacity. Biophys J. 2016;110:621-5.

41. Prabhakaran S, Rizk V, Ma Z, Cheng C, Berglund A, Coppola D, et al. Evaluation of invasive breast cancer samples using a 12-chemokine gene expression score: correlation with clinical outcomes. Breast Cancer Res. 2017;19:71-4

42. Stevanovic A, Lee P, Wilcken N. Metastatic breast cancer. Aust Fam Phys. 2006;35:309-11.

43. Page K, Guttery D, Fernandez-Garcia D, Hills A, Hastings R, Luo J, et al. Next generation sequencing of circulating cell-free DNA for evaluating mutations and gene amplification in metastatic breast cancer. Clin Chem. 2017;63:532-41.

44. Arpino G, Bardou VJ, Clark GM, Elledge RM. Infiltrating lobular carcinoma of the breast: tumor characteristics and clinical outcome. Breast Cancer Res. 2004;6:149-52.
45. Somiari R, Sullivan A, Russell S, Somiari S, Hu H, Jordan R, George A, Katenhusen R, Buchowiecka A, Arciero C, Brzeski H. High-throughput proteomic analysis of human infiltrating ductal carcinoma of the breast. Proteomics. 2003;3(10):1863-73.

46. Mateo A, Pezzi T, Sundermeyer M, Kelley C, Klimberg V, Pezzi C. Chemotherapy significantly improves survival for patients with T1c-T2N0M0 medullary Breast cancer. Ann Surg Oncol. 2017;24:1050-6.

47. Anuradha D, Lakshmi A. Mucinous carcinoma of breast with neuroendocrine differentiation: a rare case report with review of literature. Int J Res Med Sci. 2017;2:1751-4.

48. Priya $\vee$, Prasaad P. Tubulo-lobular carcinoma: a rare mixed invasive carcinoma of breast. Int J Res Med Sci. 2017;5:2818-20.

49. Joglekar-Javadekar M, Van Laere S, Bourne M, Moalwi M, Finetti P, Vermeulen PB, et al. Characterization and targeting of platelet-derived growth factor receptor alpha (PDGFRA) in inflammatory breast cancer (IBC). Neoplasia. 2017;19:564-73.

50. Cariati M, Bennett-Britton TM, Pinder SE, Purushotham AD. Inflammatory breast cancer. Surg Oncol. 2005;14:133-43.

51. Errichetti E, Avellini C, Pegolo E, De Francesco V. Dermoscopy as a supportive instrument in the early recognition of erosive adenomatosis of the nipple and mammary paget's disease. Ann Dermatol. 2017:29:365-7.

52. Merrill A, White A, Howard-McNatt M. Paget's disease of the breast: an institutional review and surgical management. Am Surg. 2017;83:96-8.

53. Strode M, Khoury T, Mangieri C, Takabe K. Update on the diagnosis and management of malignant phyllodes tumors of the breast. J Breast. 2017:33:91-6.

54. Sera T, Kashiwagi S, Takashima T, Asano Y, Goto W, limori N, et al. Multiple metastatic malignant phyllodes tumor of the breast with tonsillar metastasis: a case report. BMC Res Notes. 2017;10:55-60.

55. Nozad S, Sheehan C, Gay L, Elvin J, Vergilio J, Suh J, et al. Comprehensive genomic profiling of malignant phyllodes tumors of the breast. Breast Cancer Res Treat. 2017:162:597-602.

56. Liedtke C, Mazouni C, Hess KR, André F, Tordai A, Mejia JA, et al. Response to neoadjuvant therapy and long-term survival in patients with triple-negative breast cancer. J Clin Oncol. 2008;26:1275-81.

57. Foulkes W, Smith I, Reis-Filho J. Triple-negative breast cancer. New Engl J Med. 2010;363:1938-48.

58. Stingl J, Raouf A, Emerman JT, Eaves CJ. Epithelial progenitors in the normal human mammary gland. J Mammary Gland Biol Neoplasia. 2005; 10:49-59.

59. Villadsen R, Fridriksdottir AJ, Rønnov-Jessen L, et al. Evidence for a stem cell hierarchy in the adult human breast. J Cell Biol. 2007;177(1):87-101.

60. Stingl J, Raouf A, Eirew P, Eaves CJ. Deciphering the mammary epithelial cell hierarchy. Cell Cycle. 2006;5:1519-22.

61. Gusterson B, Warburton MJ, Mitchell D, Ellison M, Neville AM, Rudland PS. Distribution of myoepithelial cells and basement membrane proteins in the normal breast and in benign and malignant breast diseases. Cancer Res. 1982:42:4763-70.

62. Evan G, Vousden K. Proliferation, cell cycle and apoptosis in cancer. Nature. 2001:411:342-8.

63. Grana X, Reddy E. Cell cycle control in mammalian cells: role of cyclins, cyclin dependent kinases (CDKs), growth suppressor genes and cyclindependent kinase inhibitors (CKIs). Oncogene. 1995;11:211-20.

64. Hartwell L, Kastan M. Cell cycle control and cancer. Sci. 1994;266:1821-3.

65. Leighton J, Kalla R, Turner J, Fennell R. Pathogenesis of tumor invasion. Cancer Res. 1960;20:575-86.

66. Cavalieri E, Chakravarti D, Guttenplan J, Hart E, Ingle J, Jankowiak R, et al. Catechol estrogen quinones as initiators of breast and other human cancers: implications for biomarkers of susceptibility and cancer prevention. Biochim Biophys Acta. 2006;1766:63-8.

67. Jarde T, Perrier S, Vasson M, Caldefie-Chezet F. Molecular mechanisms of leptin and adiponectin in breast cancer. Eur J Cancer. 2011:47:33-43.

68. Hanahan D, Weinberg R. The hallmarks of cancer. Cell. 2000;100:57-70

69. Jain R. Normalization of tumor vasculature: an emerging concept in antiangiogenic therapy. Science. 2005;307:58-62.

70. Gupta G, Massagué J. Cancer metastasis: building a framework. Cell. 2006;127:679-95. 
71. Shamsi U, Khan S, Usman S, Soomro S, Azam I. A multicenter matched case control study of breast cancer risk factors among women in Karachi, Pakistan. Asian Pac J Cancer Prev. 2013;14:183-8.

72. Donnelly T, Khater A, Al-Bader S. Arab women's breast cancer screening practices: a literature review. Asian Pac J Cancer Prev. 2013;14(8):4519-28

73. Harirchi I, Karbakhsh M, Kashefi A, Momtahen A. Breast cancer in Iran: results of a multi-center study. Asian Pac J Cancer Prev. 2004;5:24-7.

74. Kadivar M, Mafi N, Joulaee A. Breast cancer molecular subtypes and associations with clinicopathological characteristics in Iranian women, 2002-2011. Asian Pac J Cancer Prev. 2012;13:1881-6.

75. Alegre M, Knowles M, Robison R, O'Neill K. Mechanics behind breast cancer prevention-focus on obesity, exercise and dietary fat. Asian Pac J Cancer Prev. 2013;14:2207-12.

76. Zainal N, Nik-Jaafar N, Baharudin A, Sabki Z, Ng C. Prevalence of depression in breast cancer survivors: a systematic review of observational studies. Asian Pac J Cancer Prev. 2013;14:2649-56.

77. Andsoy I, Gul A. Breast, cervix and colorectal cancer knowledge among nurses in turkey. Asian Pac J Cancer Prev. 2014;15:2267-9.

78. Franca A, Ferreira M, Franca J, Franca E, Honorio-Franca A. Breastfeeding and its relationship with reduction of breast cancer: a review. Asian Pac J Cancer Prev. 2012;13:5327-32.

79. Kruk J. Association of lifestyle and other risk factors with breast cancer according to menopausal status: a case-control study in the region of Western Pomerania (Poland). Asian Pac J Cancer Prev. 2007;8:513-4.

80. Jacobs T, Byrne C, Colditz G, Connolly J, Schnitt S. Radial scars in benign breast-biopsy specimens and the risk of breast cancer. New Engl I Med. 1999;340:430-6

81. Alco G, Igdem S, Dincer M. Vitamin D levels in patients with breast cancer: importance of dressing style. Asian Pac J Cancer Prev. 2014;15:1357-62.

82. Hasson-Ohayon I, Goldzweig G, Braun M, Galinsky D. Women with advanced breast cancer and their spouses: diversity of support and psychological distress. PsychoOncology. 2010;19:1195-204.

83. McPherson K, Steel C, Dixon J. Breast cancer-epidemiology, risk factors, and genetics. Brit Med J. 2000;321:624-8.

84. Kelsey J, Bernstein L. Epidemiology and prevention of breast cancer. Ann Rev Public Health. 1996;17:47-67.

85. Hartmann L, Sellers T, Frost M, Lingle W, Degnim A, Suman V. Benign breast disease and the risk of breast cancer. New Engl J Med. 2005;353:229-37.

86. Eberl M, Sunga A, Farrell C, Mahoney M. Patients with a family history of cancer: identification and management. JABFM. 2005;18:211-7.

87. Key T, Verkasalo P, Banks E. Epidemiology of breast cancer. The lancet Oncol. 2001;2:133-40.

88. Thomas DB. Breast cancer in men. Epidemiol Rev. 1993;15:220-31.

89. Weinberg O, Marquez-Garban D, Pietras R. New approaches to reverse resistance to hormonal therapy in human breast cancer. Drug Resist Updat. 2005:8:219-33.

90. Singh R, Kumar R. Steroid hormone receptor signalling in tumorigenesis. J Cell Biochem. 2005;96:490-505.

91. Kato S, Sato T, Watanabe T, Takemasa S, Masuhiro Y, Ohtake F. Function of nuclear sex hormone receptors in gene regulation. Cancer Chemother Pharmacol. 2005;56:4-9.

92. Malara N, Leotta A, Sidoti A, Lio S, D'Angelo R, Caparello B, et al. Ageing, hormonal behaviour and cyclin D1 in ductal breast carcinomas. Breast. 2006;15:81-9.

93. Lee H, Lee J, Gourley L, Duffy S, Day N, Estève J. Dietary effects on breast-cancer risk in Singapore. Lancet. 1991;8(337):1197-200.

94. Hulka B, Stark T. Breast cancer: cause and prevention. Lancet. 1995;346:883-7.

95. Zhao M, Howard E, Parris A, Guo Z, Zhao Q, Yang X. Alcohol promotes migration and invasion of triple-negative breast cancer cells through activation of p38 MAPK and JNK. Mol Carcinogen. 2017;56:849-62.

96. Antoniou A, Pharoah P, Narod S. Average risks of breast and ovarian cancer associated with BRCA1 or BRCA2 mutations detected in case Series unselected for family history: a combined analysis of 22 studies. Am J Hum Genet. 2003;72:1117-30.

97. Scott C, Jenkins M, Southey M. Average age-specific cumulative risk of breast cancer according to type and site of germline mutations in BRCA1 and BRCA2 estimated from multiple-case breast cancer families attending Australian family cancer clinics. Hum Genet. 2003;112:542-51.

98. Nkondjock A, Ghadirian P. Epidemiology of breast cancer among BRCA mutation carriers: an overview. Cancer Lett. 2004;205:1-8.

99. Shaukat U, Ismail M, Mehmood N. Epidemiology, major risk factors and genetic predisposition for breast cancer in the Pakistani population. Asian Pac J Cancer Prev. 2013;14:5625-9.

100. Heim E, Valach L, Schaffner L. Coping and psychosocial adaptation: longitudinal effects over time and stages in breast cancer. Psychosom Med. 1997:59:408-18.

101. Bednarek A, Sahin A, Brenner A, Johnston D, Aldaz C. Analysis of telomerase activity levels in breast cancer: positive detection at the in situ breast carcinoma stage. Clin Cancer Res. 1997;3(1):11-6.

102. Segal R, Evans W, Johnson D, Smith J, Colletta S, Gayton J. Structured exercise improves physical functioning in women with stages I and II breast cancer: results of a randomized controlled trial. J Clin Oncol. 2001;19:657-65.

103. Moran M, Schnitt S, Giuliano A, Harris J, Khan S, Horton J. Society of surgical oncology-American society for radiation oncology consensus guideline on margins for breast-conserving surgery with whole-breast irradiation in stages I and II invasive breast cancer. Int J Rad Oncol Biol Phys. 2014:88:553-64.

104. Jacquillat C, Weil M, Baillet F, Borel C, Auclerc G, Maublanc M. Results of neoadjuvant chemotherapy and radiation therapy in the breast-conserving treatment of 250 patients with all stages of infiltrative breast cancer. Cancer. 1990;66:119-29.

105. Neuman H, Morrogh M, Gonen M. Stage IV breast cancer in the Era of targeted therapy, Does surgery of the primary tumor matter. Cancer. 2015;116:1226-33.

106. Kerlikowske K, Grady D, Barclay J, Sickles EA, Eaton A, Ernster V. Positive predictive value of screening mammography by age and family history of breast cancer. JAMA. 1993;270(20):2444-50.

107. Shah R, Rosso K, Nathanson SD. Pathogenesis, prevention, diagnosis and treatment of breast cancer. World J Clin Oncol. 2014;5:283-8.

108. Kolb T, Lichy J, Newhouse J. Comparison of the performance of screening mammography, physical examination, and breast US and evaluation of factors that influence them: an analysis of 27,825 patient evaluations. Radiology. 2002;225:165-75.

109. Kosters J, Gøtzsche P. Regular self-examination or clinical examination for early detection of breast cancer. Cochrane Database Syst Rev. 2003;2:3373-5.

110. McCready T, Littlewood D, Jenkinson J. Breast self-examination and breast awareness: a literature review. J Clin Nurs. 2005;14:570-8.

111. Gursoy A, Hindistan S, Nurall N. A comparison of three educational interventions on breast self examination knowledge and health belief. Asian Pac J Cancer Prev. 2009;10:765-72.

112. Redhwan A, Al-Naggar D, Bobryshev Y, Chen R, Assabri A. Practice and barriers toward breast self-examination among young Malaysian women. Asian Pac J Cancer Prev. 2011;12:1173-8.

113. Taha $H$, Halabi Y, Berggren V. Educational intervention to improve breast health knowledge among women in Jordan. Asian Pac J Cancer Prev. 2010;11:1167-73.

114. Alipour S, Moini A, Jafari-Adli S, Gharaie N, Mansouri K. Comparison of teaching about breast cancer via mobile or traditional learning methods in gynecology residents. Asian Pac J Cancer Prev. 2012;13:4593-5.

115. Sreedharan J, Muttappallymyalil J, Venkatramana M, Thomas M. Breast self-examination and practice among nurses in United Arab Emirates. Asian Pac J Cancer Prev. 2010;11:651-4.

116. Ozkan A, Malak A, Gürkan A, Turgay A. Do Turkish nursing and midwifery students teach breast self examination to their relatives. Asian Pac J Cancer Prev. 2010;11:1569-73.

117. Ceber E, Mermer G, Okcin F. Breast cancer risk and early diagnosis applications in Turkish women aged 50 and over. Asian Pac J Cancer Prev. 2013;14:5877-82.

118. Beydag K, Karaoğlan P. The effect of breast self examination (Bse) education given to midwifery students on their knowledge and attitudes. Asian Pac J Cancer Prev. 2010;11:1761-4.

119. Berg W, Blume J, Cormack J, Mendelson E, Lehrer D, Bohm-Velez M, et al. Combined screening with ultrasound and mammography vs mammography alone in women at elevated risk of breast cancer. JAMA. 2008;299:2151-63. 
120. Masood S, Rosa M. Borderline breast lesions: diagnostic challenges and clinical implications. Adv Anat Pathol. 2011;18:190-8.

121. Kelly K, Dean J, Comulada W, Lee S. Breast cancer detection using automated whole breast ultrasound and mammography in radiographically dense breasts. Eur Radiol. 2010;20:734-42.

122. Ahmed B. Awareness and practice of breast cancer and breast self examination among university students in Yemen. Asian Pac J Cancer Prev. 2010;11:101-6.

123. Cam O, Gvmvs A. Breast cancer screening behavior in Turkish women: relationships with health beliefs and self-esteem, body, perception and hopelessness. Asian Pac J Cancer Prev. 2009;10:49-56.

124. Husarik D, Steinert H. Single-photon emission computed tomography/ computed tomography for sentinel node mapping in breast cancer. Semin Nuclear Med. 2007;37:29-33.

125. Antoch G, Saoudi N, Kuehl H, Dahmen G, Mueller SP, Beyer T, et al. Accuracy of whole-body dual-modality fluorine-18-2-fluoro-2-deoxyD-glucose positron emission tomography and computed tomography (FDG-PET/CT) for tumor staging in solid tumors: comparison with CT and PET. J Clin Oncol. 2004;22:4357-68.

126. Porika M, Malotu N, Veldandi U-K. Evaluation of tumor markers in Southern Indian breast cancer patients. Asian Pac J Cancer Prev. 2010:2010(11):157-9.

127. Harris $L$, Fritsche $H$, Mennel R, Norton L, Ravdin P, Taube $S$, et al. American Society of Clinical Oncology 2007 update of recommendations for the use of tumor markers in breast cancer. J Clin Oncol. 2007;25:5287-312.

128. Hayes DF. Tumor markers for breast cancer. Ann Oncol. 1993;4:807-19.

129. Khazai L, Rosa M. Use of immunohistochemical stains in epithelial lesions of the breast. Cancer Control. 2015:22:220-5.

130. Nystrom L, Andersson I, Bjurstam N, Frisell J, Nordenskjöld B, Rutqvist L. Long-term effects of mammography screening: updated overview of the Swedish randomised trials. Lancet. 2002;359:909-19.

131. Richardson H, Johnston D, Pater J, Goss P. The national cancer institute of Canada clinical trials group MAP.3 trial: an international breast cancer prevention trial. Curr Oncol. 2007;14:89-96.

132. Boughey J, Nguyen T. Axillary staging after neoadjuvant chemotherapy for breast cancer: a pilot study combining sentinel lymph node biopsy with radioactive seed localization of pre-treatment positive axillary lymph bodes. Breast Dis YB Quart. 2016;27:282-4.

133. Sotiriou C, Powles TJ, Dowsett M, Jazaeri AA, Feldman AL, Assersohn L, Gadisetti C, Libutti SK, Liu ET. Gene expression profiles derived from fine needle aspiration correlate with response to systemic chemotherapy in breast cancer. Breast Cancer Res. 2002;4(3):3-7.

134. Kuenen-Boumeester V, Menke-Pluymers M, Kanter A, Obdeijn I, Urich D, Kwast T. Ultrasound-guided fine needle aspiration cytology of axillary lymph nodes in breast cancer patients. Eur J Cancer. 2003;39:170-4.

135. Elvecrog EL, Lechner MC, Nelson MT. Nonpalpable breast lesions: correlation of stereotaxic large-core needle biopsy and surgical biopsy results. Radiology. 1993;188(2):453-5.

136. Liberman L, Dershaw DD, Rosen PP, Abramson AF, Deutch BM, Hann LE. Stereotaxic 14-gauge breast biopsy: how many core biopsy specimens are needed. Radiology. 1994;192(3):793-5.

137. Damera A, Evans A, Cornford E, Wilson A, Burrell H, James J, et al. Diagnosis of axillary nodal metastases by ultrasound-guided core biopsy in primary operable breast cancer. Brit J Cancer. 2003;89:1310.

138. Jackman R, Burbank F, Parker S, Evans P, Lechner C, Richardson T, et al. Atypical ductal hyperplasia diagnosed at stereotactic breast biopsy: improved reliability with 14-gauge, directional, vacuum-assisted biopsy. Radiology. 1997;204:485-8.

139. Burak W, Owens K, Tighe M, Kemp L, Dinges S, Olsen J. Vacuum-assisted stereotactic breast biopsy: histologic underestimation of malignant lesions. Arch Surg. 2000;135:700-3.

140. Krag D, Weaver D, Alex J, Fairbank J. Surgical resection and radiolocalization of the sentinel lymph node in breast cancer using a gamma probe. Surg Oncol. 1993;2:335-40.

141. Lyman G, Temin S, Edge S, Newman L, Turner R, Weaver D, et al. Sentinel lymph node biopsy for patients with early-stage breast cancer: American Society of Clinical Oncology clinical practice guideline update. J Clin Oncol. 2014:32:1365-83.
142. Abdulkareem S. Breast magnetic resonance imaging indications in current practice. Asian Pac J Cancer Prev. 2014;2:569-75.

143. Ahmadian M, Samah A, Redzuan M, Emby Z. Predictors of mammography screening among Iranian women attending outpatient clinics in Tehran, Iran. Asian Pac J Cancer Prev. 2012;13:969-74.

144. Wang F, Chen F, Yin H. Effects of age, breast density and volume on breast cancer diagnosis: a retrospective comparison of sensitivity of mammography and ultrasonography in China's rural areas. Asian Pac J Cancer Prev. 2013;4:2277-82.

145. Kanaga K, Nithiya J, Shatirah M. Awareness of breast cancer and screening procedures among Malaysian women. Asian Pac J Cancer Prev. 2011;12:1965-7.

146. Sardanelli F, Giuseppetti G, Panizza P, Bazzocchi M, Fausto A, Simonetti $\mathrm{G}$, et al. Sensitivity of MRI versus mammography for detecting foci of multifocal, multicentric breast cancer in fatty and dense breasts using the whole-breast pathologic examination as a gold standard. Am J Roentgenol. 2004;183:1149-57.

147. Smith R, Caleffi M, Albert S, Tony H, Stephen W, Franceschi D. Breast cancer in limited resource countries: early detection and access to care. Breast J. 2006:12:16-26.

148. Berg W, Weinberg I, Narayanan D, Lobrano M, Ross E, Levine E. Highresolution fluorodeoxyglucose positron emission tomography with compression ("positron emission mammography") is highly accurate in depicting primary breast cancer. Breast J. 2006;12(4):309-23.

149. Schilling K, Narayanan D, Judith E, Velasquez M, Kahn S, Saady M. Positron emission mammography in breast cancer presurgical planning: comparisons with magnetic resonance imaging. Eur J Nucl Med Mol Imaging. 2011;38:23-36.

150. Meng X, Sun H, Yang L, Yin R, Qi L. A hydroxylated flavonol, fisetin inhibits the formation of a carcinogenic estrogen metabolite. Steroids. 2017;31(119):53-6.

151. Oshima S, Kisa K, Terashita T. A qualitative study of Japanese patients' perspectives on post-treatment care for gynecological cancer. Asian Pac J Cancer Prev. 2011;12:2255-61.

152. Sharifa E, Fuad I, Hayati Y. Observational Study on patient's satisfactions and quality of life (QoL) among cancer patients receiving treatment with palliative care intent in a tertiary hospital in Malaysia. Asian Pac J Cancer Prev. 2014;15:695-701.

153. Shen F, Liu M, Zhang X. Health-related quality of life among breast cancer patients and its influencing factor in a Chinese population. Asian Pac J Cancer Prev. 2012;13:3747-50.

154. Lodha R, Nandeshwar S, Pal D. Risk factors for breast cancer among women in Bhopal urban agglomerate: a case-control study. Asian Pac J Cancer Prev. 2011:12:2111-5.

155. Debnath M, Malik C, Bisen P. Micropropagation: a tool for the production of high quality plant-based medicines. Curr Pharm Biotechnol. 2006;7(1):33-9.

156. Mehta R, Murillo G, Naithani R, Peng X. Cancer chemoprevention by natural products: how far have we come. Pharm Res. 2010;27:950-61.

157. Deng Q, Huang X, Ye L. Phase II trial of Loubo ${ }^{\circledR}$ (Lobaplatin) and Pemetrexed for patients with metastatic breast cancer not responding to anthracycline or taxanes. Asian Pac J Cancer Prev. 2013;14:413-7.

158. Huang S, Cao K. Anti-invasive and anti-metastasis effect of norcantharidin on high-metastatic human breast cancer cell lines. J Trop Med. 2010;9:1034-45.

159. Savard J, Simard S, Ivers H, Morin CM. Randomized study on the efficacy of cognitive-behavioral therapy for insomnia secondary to breast cancer, part I: sleep and psychological effects. J Clin Oncol. 2005:23:6083-96.

160. Compas BE, Luecken L. Psychological adjustment to breast cancer. Curr Direct Psychol Sci. 2002;11:111-4.

161. Ellis M, Suman V, Hoog J, Goncalves R, Sanati S, Creighton CJ, et al. Ki67 proliferation index as a tool for chemotherapy decisions during and after neoadjuvant aromatase inhibitor treatment of breast cancer: results from the American college of surgeons oncology group Z1031 trial (Alliance). J Clin Oncol. 2017:35:1061-9.

162. Houssami N, Turner R, Morrow M. Meta-analysis of pre-operative magnetic resonance imaging (MRI) and surgical treatment for breast cancer. Breast Cancer Res Treat. 2017;6:1-11. 
163. Pearson R, Milligan R, Cain H. Radioactive iodine-125 seed localisation of breast carcinoma in advance of the day of surgery reduces preoperative anxiety levels. Europ J Surg Oncol. 2017;43:7-10.

164. Vaz-Luis I, Hughes ME, Cronin A, Rugo HS, Edge SB, Moy B, Theriault RL, Hassett MJ, Winer EP, Lin NU. Trends in the use of mastectomy in women with small node-negative breast cancer treated at US academic centers. Breast Cancer Res Treat. 2016;155(3):569-78.

165. Fisher B, Anderson S, Redmond C, Cronin W. Reanalysis and results after 12 years of follow-up in a randomized clinical trial comparing total mastectomy with lumpectomy with or without irradiation in the treatment of breast cancer. New Engl J Med. 1995;333:1456-61.

166. Dorval M, Maunsell E, Deschênes L, Brisson J. Type of mastectomy and quality of life for long term breast carcinoma survivors. Cancer. 1998:83:2130-8

167. Yarnold J, Ashton A, Bliss J, Homewood J, Harper C, Hanson J. Fractionation sensitivity and dose response of late adverse effects in the breast after radiotherapy for early breast cancer: long-term results of a randomised trial. Radiother Oncol. 2005;75:9-17.

168. Voogd A, Nielsen M, Peterse JL, Blichert-Toft M, Bartelink H, Overgaard $\mathrm{M}$, et al. Danish breast cancer cooperative group and the breast cancer cooperative group of the European organization for research and treatment of cancer. Differences in risk factors for local and distant recurrence after breast-conserving therapy or mastectomy for stage I and II breast cancer: pooled results of two large European randomized trials. J Clin Oncol. 2001;19:1688-97.

169. RebbeckT, Friebel T, Lynch H, Neuhausen S, Veer L, Garber J, et al. Bilateral prophylactic mastectomy reduces breast cancer risk in BRCA1 and BRCA2 mutation carriers: the PROSE Study Group. J Clin Oncol. 2004;22:1055-62.

170. Tuttle T, Habermann E, Grund E, Morris T, Virnig B. Increasing use of contralateral prophylactic mastectomy for breast cancer patients: a trend toward more aggressive surgical treatment. J Clin Oncol. 2007:25:5203-9.

171. Keskin G, Gumus A. Turkish hysterectomy and mastectomy patientsdepression, body image, sexual problems and spouse relationships. Asian Pac J Cancer Prev. 2011;12:425-32.

172. Rowland JH, Desmond KA, Meyerowitz BE, Belin TR, Wyatt GE. Role of breast reconstructive surgery in physical and emotional outcomes among breast cancer survivors. J Nat Cancer Instit. 2000;92:1422-9.

173. Parker P, Youssef A, Walker S. Short-term and long-term psychosocial adjustment and quality of life in women undergoing different surgical procedures for breast cancer. Ann Surg Oncol. 2007;14:3078-89.

174. Elder EE, Brandberg Y, Björklund T. Quality of life and patient satisfaction in breast cancer patients after immediate breast reconstruction: a prospective study. Breast. 2005;14:201-8.

175. Thomson C, Twelves C, Mallon E, Leake R, Group S. Scottish cancer therapy network. adjuvant ovarian ablation vs CMF chemotherapy in premenopausal breast cancer patients: trial update and impact of immunohistochemical assessment of ER status. Breast. 2002;11:419-29.

176. Davidson N. Ovarian ablation as adjuvant therapy for breast cancer. Semin Oncol. 2001;30:67-71.

177. Hammond M, Hayes D, Dowsett M, Allred D, Hagerty K, Badve S, et al. American Society of Clinical Oncology/College of American Pathologists guideline recommendations for immunohistochemical testing of estrogen and progesterone receptors in breast cancer (unabridged version). Arch Pathol Lab Med. 2010;134:48-72.

178. Osborne C, Yochmowitz M, Knight W, McGuire W. The value of estrogen and progesterone receptors in the treatment of breast cancer. Cancer. 1980:46:2884-8.

179. Clarke R, Liu M, Bouker K, Gu Z, Lee R, Zhu Y. Antiestrogen resistance in breast cancer and the role of estrogen receptor signaling. Oncogene. 2003:22:7316-39.

180. Mehta S, Dhandapani K, De Sevilla L, Webb R, Mahesh V. Tamoxifen, a selective estrogen receptor modulator, reduces ischemic damage caused by middle cerebral artery occlusion in the ovariectomized female rat. Neuroendocrinology. 2003;77:44-50.

181. Man S, Bocci G, Francia G, Green S, Jothy S, Hanahan D. Antitumor effects in mice of low-dose (metronomic) cyclophosphamide administered continuously through the drinking water. Cancer Res. 2002;62:2731-5.
182. Visvanathan K, Chlebowski R, Hurley P, Col F, Ropka M, Collyar D. American society of clinical oncology clinical practice guideline update on the use of pharmacologic interventions including tamoxifen, raloxifene, and aromatase inhibition for breast cancer risk reduction. J Clin Oncol. 2009:27:3235-58.

183. Journe F, Body J, Leclercq G, Laurent G. Hormone therapy for breast cancer, with an emphasis on the pure antiestrogen fulvestrant: mode of action, antitumor efficacy and effects on bone health. Exp Opin Drug Safe. 2008;7:241-58

184. Riggs B, Hartmann L. Selective estrogen-receptor modulators-mechanisms of action and application to clinical practice. New Engl J Med. 2003;348:618-29.

185. Nayfield S, Karp J, Ford L, Dorr F, Kramer B. Potential role of tamoxifen in prevention of breast cancer. J Nat Cancer Inst. 1991;83:1450-9.

186. Jordan V. New insights into the metabolism of tamoxifen and its role in the treatment and prevention of breast cancer. Steroids. 2007;72:829-42.

187. Fisher B, Costantino J, Wickerham D, Redmond C, Kavanah M, Cronin W, et al. Tamoxifen for prevention of breast cancer: report of the national surgical adjuvant breast and bowel project P-1 Study. J Nat Cancer Inst. 1998;90:1371-88.

188. Fisher B, Costantino J, Wickerham D. Tamoxifen for prevention of breast cancer: report of the National Surgical Adjuvant Breast and Bowel Project P-1 Study. J Natl Cancer Inst. 1998;90:1371-88.

189. Vogel V, Costantino J, Wickerham D. Effects of tamoxifen vs raloxifene on the risk of developing invasive breast cancer and other disease outcomes: the NSABP study of tamoxifen and raloxifene (STAR) P-2 trial. JAMA. 2006;295:2727-41.

190. Cuzick J, Powles T, Veronesi U. Overview of the main outcomes in breast-cancer prevention trials. Lancet. 2003;361:296-300.

191. Cuzick J, Forbes J, Sestak I. Long-term results of tamoxifen prophylaxis for breast cancer-96-month follow-up of the randomized IBIS-I trial. J Natl Cancer Inst. 2007:99:272-82.

192. Mortimer J, Urban J. Long-term toxicities of selective estrogen-receptor modulators and antiaromatase agents. J Oncol. 2003;17:652-9.

193. Vogel V. Chemoprevention strategies 2006. Curr Treat Options Oncol. 2007:8:74-88.

194. Land S, Wickerham D, Costantino J. Patient-reported symptoms and quality of life during treatment with tamoxifen or raloxifene for breast cancer prevention: the NSABP Study of Tamoxifen and Raloxifene (STAR) P-2 trial. JAMA. 2006;295:2742-51.

195. Goss P, Strasser K. Aromatase inhibitors in the treatment and prevention of breast cancer. J Clin Oncol. 2001;19:881-94.

196. Winer E, Hudis C, Burstein H, Wolff A, Pritchard K, Ingle J, et al. American Society of Clinical Oncology technology assessment on the use of aromatase inhibitors as adjuvant therapy for postmenopausal women with hormone receptor-positive breast cancer: status report 2004.J Clin Oncol. 2005;23:619-29.

197. Hall E, Brenner D. Cancer risks from diagnostic radiology. Br J Radiol. 2008;81:362-78.

198. Nandi M, Mahata A, Mallick I. Hypofractionated radiotherapy for breast cancers-preliminary results from a tertiary care center in eastern India. Asian Pac J Cancer Prev. 2014;15:2505-10.

199. Zhou S, Shi W, Meng D. Interoperative radiotherapy of seventy-two cases of early breast cancer patients during breast-conserving surgery. Asian Pac J Cancer Prev. 2012;13:1131-5.

200. Keisch M, Vicini F, Kuske R, Hebert M, White J, Quiet C, et al. Initial clinical experience with the MammoSite breast brachytherapy applicator in women with early-stage breast cancer treated with breast-conserving therapy. Int J Radiat Oncol Biol Phys. 2003;55:289-93.

201. King A, Bolton J, Kuske R, Fuhrman G, Scroggins T, Jiang X. Long-term results of wide-field brachytherapy as the sole method of radiation therapy after segmental mastectomy for T is, 1, 2 breast cancer. Am J Surg. 2000;180:299-304.

202. Johnstone R, Ruefli A, Lowe S. Apoptosis: a link between cancer genetics and chemotherapy. Cell. 2002;108:153-64.

203. Masood S. Neoadjuvant chemotherapy in breast cancers. Womens Health (Lond). 2016;12:480-91.

204. Benson I, Schrag D, Somerfield M, Cohen A, Figueredo A, Flynn P. American society of clinical oncology recommendations on adjuvant chemotherapy for stage II colon cancer. J Clin Oncol. 2004;22(16):3408-19. 
205. Shapiro C, Recht A. Side effects of adjuvant treatment of breast cancer. New Engl J Med. 2001;344:1997-2008.

206. Muller A, Homey B, Soto H, Ge N. Involvement of chemokine receptors in breast cancer metastasis. Nature. 2001;410:50-5.

207. Miller K, Wang M, Gralow J, Dickler M, Cobleigh M, Perez E. Paclitaxel plus bevacizumab versus paclitaxel alone for metastatic breast cancer. New Engl J Med. 2007:357:2666-76.

208. Ringel I, Horwitz S. Studies with RP 56976 (taxotere): a semisynthetic analogue of taxol. J Nat Cancer Inst. 1991;83:288-91.

209. Wist E, Sommer H, Ostenstad B, Risberg T, Fjaestad K. Weekly 1-hour paclitaxel as first-line chemotherapy for metastatic breast cancer. Acta Oncol. 2004;43:11-4.

210. Tan D, Marchió C, Jones R, Savage K, Smith I, Dowsett M, et al. Triple negative breast cancer: molecular profiling and prognostic impact in adjuvant anthracycline-treated patients. Breast Cancer Res Treat. 2008;111:27-44

211. Oshaughnessy J, Miles D, Vukelja S, Moiseyenko V, Ayoub JP, Cervantes $\mathrm{G}$, et al. Superior survival with capecitabine plus docetaxel combination therapy in anthracycline-pretreated patients with advanced breast cancer: phase III trial results. J Clin Oncol. 2002;20:2812-23.

212. Grevelman E, Breed W. Prevention of chemotherapy-induced hair loss by scalp cooling. Ann Oncol. 2005:16:352-8.

213. Monsuez J, Charniot JC, Vignat N, Artigou JY. Cardiac side-effects of cancer chemotherapy. Int J Cardiol. 2010;144:3-15.

214. Digianni L, Garber J, Winer E. Complementary and alternative medicine use among women with breast cancer. J Clin Oncol. 2002;2002(20):34-8

215. Yates J, Mustian K, Morrow G, Gillies L, Padmanaban D, Atkins J. Prevalence of complementary and alternative medicine use in cancer patients during treatment. Support Care Cancer. 2005;13:806-11.

216. Linde K, Jonas W, Melchart D, Willich S. The methodological quality of randomized controlled trials of homeopathy, herbal medicines and acupuncture. Int J Epidemiol. 2001;30:526-31.

217. Thorne S, Paterson B, Russell C, Schultz A. Complementary/alternative medicine in chronic illness as informed self-care decision making. Int $J$ Nurs Stud. 2002;39:671-83.

218. Wang S, Hsu L, Hsu H, Lee S, Shiao M, Ho C. The anti-tumor effect of Ganoderma lucidum is mediated by cytokines released from activated macrophages and T lymphocytes. Int J Cancer. 1997;70:699-705.

219. Jiang J, Slivova V, Harvey K. Ganoderma lucidum suppresses growth of breast cancer cells through the inhibition of Akt/NF-kappaB signaling. Nutr Cancer. 2004:49:209-16.

220. Harinantenaina L, Tanaka M, Takaoka S, Oda M, Mogami O, Uchida M. Momordica charantia constituents and antidiabetic screening of the isolated major compounds. Chem Pharm Bull. 2006;54:1017-21.

221. Basch E, Gabardi S, Ulbricht C. Bitter melon (Momordica charantia): a review of efficacy and safety. Amer $J$ HealthSyst Pharm. 2003;60:356-9.

222. Ray B, Raychoudhuri A, Steele R. Bitter melon (Momordica charantia) extract inhibits breast cancer cell proliferation by modulating cell cycle regulatory genes and promotes apoptosis. Cancer Res. 2010;70:1925-31.

223. Roh J, Han J, Kim J, Hwang J. Inhibitory effects of active compounds isolated from safflower (Carthamus tinctorius $\mathrm{L}$.) seeds for melanogenesis. Biol Pharm Bull. 2004:27:1976-8.

224. Zhang H, Nagatsu A, Watanabe T. Antioxidative compounds isolated from safflower (Carthamus tinctorius L.) oil cake. Chem Pharm Bull. 1997:45:1910-4.

225. Takahashi T, Miyazawa M. Potent a-glucosidase inhibitors from safflower (Carthamus tinctorius L.) seed. Phytother Res. 2012;26:722-6.

226. Loo T, Cheung N, Chow W. The inhibitory effect of herbal formula comprising ginseng and Carthamus tinctorius on breast cancer. Life Sci. 2004;76:191-200.

227. Urech K, Scher J, Hostanska K, Becker H. Apoptosis inducing activity of viscin, a lipophilic extract from Viscum album L. J Pharm Pharmacol. 2005:57:101-9.

228. Grossarth-Maticek R, Kiene H, Baumgartner S, Ziegler R. Use of Iscador an extract of European mistletoe (Viscum album), in cancer treatment: prospective nonrandomized and randomized matched-pair studies nested within a cohort study. Altern Ther Health Med. 2001;7:57.
229. Gunver S, Anja G, Michael S. Viscom album extracts in breast and gynaecological cancers: a systematic review of clinical and preclinical research. J Exp Clin Cancer Res. 2009;28:79.

230. Pintea A, Bele C, Andrei S, Socaciu C. HPLC analysis of carotenoids in four varieties of Calendula officinalis L. flowers. Acta Biol. 2003:47:37-40.

231. Ukiya M, Akihisa T, Yasukawa K, Tokuda H, Suzuki T. Anti-inflammatory, anti-tumor-promoting, and cytotoxic activities of constituents of marigold (Calendula officinalis) flowers. J Nat Products. 2006;69:1692-6.

232. Pommier P. Gomez F, Sunyach P. Phase III randomized trial of Calendula officinalis compared with trolamine for the prevention of acute dermatitis during irradiation for breast cancer. J Clin Oncol. 2004:22:1447-53.

233. Delazar A, Gibbons S, Kosari A, Nazemiyeh H, Modarresi M, Nahar L. Flavone C-glycosides and cucurbitacin glycosides from Citrullus colocynthis. DARU J Pharm Sci. 2006;14:109-14.

234. Tannin-Spitz T, Grossman S, Dovrat S, Gottlieb H, Bergman M. Growth inhibitory activity of cucurbitacin glucosides isolated from Citrullus colocynthis on human breast cancer cells. Biochem Pharmacol. 2007:73:56-67.

235. Kumar S, Kumar D, Jusha M, Saroha K, Singh N, Vashishta B. Antioxidant and free radical scavenging potential of Citrullus colocynthis (L.) Schrad. methanolic fruit extract. Acta Pharm. 2008;58:215-20.

236. Weng J, Tsai C, Kulp S, Chen C. Indole-3-carbinol as a chemopreventive and anti-cancer agent. Cancer Lett. 2008;262:153-63.

237. Maasomi Z, Soltanahmadi Y, Dadashpour M, Alipour S, Abolhasani S, Zarghami N. Synergistic anticancer effects of silibinin and chrysin in T47D breast cancer cells. Asian Pac J Cancer Prev. 2017;18:1283-7.

238. Maroof H, Hassan Z, Mobarez A, Mohamadabadi M. Lactobacillus acidophilus could modulate the immune response against breast cancer in murine model. J Clin Immunol. 2012;1:1-7.

239. McConnell K, Jager R, Bland K, Blotcky A. The relationship of dietary selenium and breast cancer. J Surg Oncol. 1980:15:67-70.

240. Smith I, Procter M, Gelber RD, Guillaume S, Feyereislova A, Dowsett M, et al. 2-year follow-up of trastuzumab after adjuvant chemotherapy in HER2-positive breast cancer: a randomised controlled trial. Lancet. 2007;369:29-36.

241. Vogel C, Cobleigh M, Tripathy D, Gutheil J, Harris L, Fehrenbacher L, et al. Efficacy and safety of trastuzumab as a single agent in first-line treatment of HER2-overexpressing metastatic breast cancer. J Clin Oncol. 2002;20:719-26.

242. Liang Q, Li W, Zhao Z, Fu Q. Advancement of Wnt signal pathway and the target of breast cancer. Open Life Sci. 2016;11:98-104.

243. Churpek JE, Marquez R, Neistadt B, Claussen K, Lee MK, Churpek MM, Huo D, Weiner H, Bannerjee M, Godley LA, Le Beau MM. Inherited mutations in cancer susceptibility genes are common among survivors of breast cancer who develop therapy-related leukemia. Cancer. 2016;122(2):304-11.

244. Bon E, Driffort V, Gradek F, Martinez-Caceres C, Anchelin M, Pelegrin P, et al. SCN4B acts as a metastasis-suppressor gene preventing hyperactivation of cell migration in breast cancer. Nat Commun. 2016;7:136-8.

245. Nik-Zainal S, Davies H, Staaf J, Ramakrishna M, Glodzik D, Zou X, et al. Landscape of somatic mutations in 560 breast cancer whole-genome sequences. Nature. 2016;534:47-54.

246. Manchanda R, Jacobs I. Genetic screening for gynecological cancer: where are we heading? Future Oncol. 2016;12(2):207-20.

247. Obermiller P. Tait D, Holt J. Gene therapy for carcinoma of the breast: therapeutic genetic correction strategies. Breast Cancer Res. 1999;2:28-30.

248. Karin M, Greten FR. NF-[kappa] B: linking inflammation and immunity to cancer development and progression. Nature Rev Immunol. 2005:5:749-52.

249. Osborne C, Wilson P, Tripathy D. Oncogenes and tumor suppressor genes in breast cancer. Potential diagnostic and therapeutic applications. Oncologist. 2004;4:361-77.

250. Sharma G, Dave R, Sanadya J, Sharma P, Sharma K. Various types and management of breast cancer: an overview. J Adv Pharm Technol Res. 2010;1:109-11.

251. Ricardo S, Vieira AF, Gerhard R, Leitão D, Pinto R, Cameselle-Teijeiro JF, Milanezi F, Schmitt F, Paredes J. Breast cancer stem cell markers CD44, CD24 and ALDH1: expression distribution within intrinsic molecular subtype. J Clin Pathol. 2011;64(11):937-46. 
252. Kakarala M, Wicha M. Implications of the cancer stem-cell hypothesis for breast cancer prevention and therapy. J Clin Oncol. 2008;26:2813-20.

253. Noyce P. Improving long-term adjuvant anti-oestrogenic therapy for breast cancer. New Commun. 2017;13:43-7.

254. Shibata T, Watari K, Izumi H, Kawahara A, Hattori S, Fukumitsu C, et al. Breast cancer resistance to antiestrogens is enhanced by increased ER degradation and ERBB2 expression. Cancer Res. 2017;77:545-56.

255. Awolaran T. Cellular mechanisms of estrogen in breast cancer development. J Sci Technol. 2015;3:1-7.

256. Slamon D, Leyland-Jones B, Shak S, Fuchs H, Paton V, Bajamonde A, et al. Use of chemotherapy plus a monoclonal antibody against HER2 for metastatic breast cancer that overexpresses HER2. New Engl J Med. 2001;344(11):783-92.

257. Stopeck A, Lipton A, Body J, Steger G, Tonkin K, De Boer R, et al. Denosumab compared with zoledronic acid for the treatment of bone metastases in patients with advanced breast cancer: a randomized, double-blind study. J Clin Oncol. 2010;28:5132-9.
258. Hadden J. Review Article The immunology and immunotherapy of breast cancer: an update. Int J Immunopharmacol. 1999;21:79-101.

259. Wright S. Immunotherapy of breast cancer. Expert Opin Biol Ther. 2012:12:479-90.

260. Ono M. Molecular links between tumor angiogenesis and inflammation: inflammatory stimuli of macrophages and cancer cells as targets for therapeutic strategy. Cancer Sci. 2008;99:1501-6.

261. Mu J, Zhu D, Shen Z, Ning S, Liu Y, Chen J. The repressive effect of miR148a on Wnt/ $\beta$-catenin signaling involved in Glabridin-induced antiangiogenesis in human breast cancer cells. BMC Cancer. 2017;17:307-9.

262. de Bock G, Bonnema J, van der Hage J, Kievit J, van de Velde C. Effectiveness of routine visits and routine tests in detecting isolated locoregional recurrences after treatment for early-stage invasive breast cancer: a meta-analysis and systematic review. J Clin Oncol. 2004;22:4010-8.

\section{Submit your next manuscript to BioMed Central and we will help you at every step:}

- We accept pre-submission inquiries

- Our selector tool helps you to find the most relevant journal

- We provide round the clock customer support

- Convenient online submission

- Thorough peer review

- Inclusion in PubMed and all major indexing services

- Maximum visibility for your research

Submit your manuscript at www.biomedcentral com/submit 